\title{
Combretaceae no estado do Rio Grande do Norte, Brasil
}

\author{
Combretaceae of Rio Grande do Norte state, Brasil
}

\author{
Valdeci Fontes de Sousa ${ }^{1,4}$, Rayane de Tasso Moreira Ribeiro ${ }^{2}$, Maria Iracema Bezerra Loiola $^{3}$ \\ \& Leonardo M. Versieux ${ }^{1}$
}

\begin{abstract}
Resumo
Aqui se apresenta a Flora de Combretaceae do Rio Grande do Norte, Nordeste do Brasil, com base na análise comparativa dos caracteres morfológicos de espécimes depositados nos herbários ASE, EAC, FUEL, HEPH, HST, HUEFS, IPA, JPB, MAC, MBM, MOSS, NY, UEC e UFRN, bibliografias especializadas e fotos de coleções-tipo. Para o Rio Grande do Norte são registradas 12 espécies em cinco gêneros: Buchenavia (1 sp.), Combretum (7 spp.), Conocarpus (1 sp.), Laguncularia (1 sp.) e Terminalia (2 spp.). Combretum duarteanum Cambess., C. fruticosum, T. mameluco são novos registros para o estado e Terminalia cf. amazonia poderá ser confirmada como tal, a partir de coleta de espécimes completos. Chaves de identificação para gêneros e espécies, descrições, dados de distribuição geográfica, comentários taxonômicos e ilustrações das espécies são fornecidos.
\end{abstract}

Palavras-chave: Brazil Flora Group, Combreteae, Combretum, Laguncularieae, taxonomia.

\begin{abstract}
Here we present the Combretaceae flora for Rio Grande do Norte state, Northeastern region of Brazil, based on morphological analyses of specimens deposited in the herbaria ASE, EAC, FUEL, HEPH, HST, HUEFS, IPA, JPB, MAC, MBM, MOSS, NY, UEC, and UFRN, bibliography and images of type specimens. Twelve species belonging to five genera are recorded: Buchenavia (1 sp.), Combretum (7 spp.), Conocarpus (1 sp.), Laguncularia (1 sp.) and Terminalia (2 spp.). Combretum duarteanum, C. fruticosum, and T. mameluco are considered new records for the state while Terminalia $\mathrm{cf}$. amazonia may also be a new record depending upon the collection of complete specimens to have its identity confirmed. Identification keys to genera and species, descriptions, geographic distribution, taxonomic comments and illustrations are provided.
\end{abstract}

Key words: Brazil Flora Group, Combreteae, Combretum, Laguncularieae, taxonomy.

\section{Introdução}

Combretaceae R. Br. compreende 14 gêneros e aproximadamente 500 espécies (Stace 2010) distribuídas nas regiões tropicais e subtropicais, sendo a África o seu principal centro de diversidade (Linsingen et al. 2009; Stace 2010). Encontra-se dividida nas subfamílias Strephonematoideae e Combretoideae, a última abrangendo as tribos Laguncularieae e Combreteae (Exell \& Stace 1966). Para a flora brasileira, são registradas 64 espécies (13 endêmicas) agregadas em cinco gêneros e encontradas nos domínios fitogeográficos da Amazônia, Caatinga, Cerrado, Mata Atlântica e Pantanal (BFG 2015). Em relação a sua importância econômica, as espécies possuem diversas finalidades dentre as quais se destacam a madeireira e a farmacológica (Marquete 1995; Stace 2010).

Os representantes de Combretaceae apresentam hábito arbóreo, arbustivo escandente ou lianescente (Combretum Loefl.); folhas opostas, alternas ou verticiladas, simples, inteiras, sem estípulas; inflorescências em espigas, racemos ou

\footnotetext{
${ }^{1}$ Universidade Federal do Rio Grande do Norte, Prog. Pós-graduação em Ciências Florestais, RN-160, km 3, Distrito de Jundiaí, 59280-000, Macaíba, RN, Brasil.

${ }^{2}$ Universidade Federal Rural de Pernambuco, Depto. Biologia, Prog. Pós-graduação em Botânica, R. Dom Manoel de Medeiros s/n, Dois Irmãos, 52171-900, Recife, PE, Brasil.

${ }^{3}$ Universidade Federal do Ceará, Depto. Biologia, Lab. Sistemática e Ecologia Vegetal (LASEV), Herbário EAC, bl. 906, Campus do Pici Prof. Prisco Bezerra, 60440-900, Fortaleza, CE, Brasil.

${ }^{4}$ Autor para correspondência: valdeci.fontes@yahoo.com.br
} 
panículas, às vezes em glomérulos (Conocarpus L.), terminais ou axilares; flores actinomorfas ou zigomorfas, bissexuais, às vezes unissexuais, raramente dioicas (Conocarpus), tetrâmeras ou pentâmeras, com hipanto dividido em duas regiões, uma inferior em torno do ovário (hipanto inferior) e uma superior formando os lobos do cálice (hipanto superior); bractéolas ausentes ou, quando presentes, adnatas ao hipanto; estames diplostêmones, exsertos; ovário ínfero, unilocular; frutos drupa ou betulídios com uma semente (Loiola 2009b; Stace 2010).

No Brasil, os representantes de Combretaceae foram estudados em todas as regiões e citados em floras regionais e locais. Na Região Sudeste destacam-se os trabalhos de Marquete (1984, 1995), Marquete \& Valente (1997) e Marquete et al. (2003); na Região Norte, Marquete \& Valente (2005); na Região Sul, Exell \& Reitz (1967), Linsingen \& Cervi (2008) e Linsingen et al. (2009) e no Centro-Oeste, Marquete \& Valente (1996, 2003). Para o Nordeste, destacam-se os estudos desenvolvidos por Loiola \& Sales (1996) que registraram os representantes de Combretum ocorrentes em Pernambuco; Loiola et al. (2009) que listaram as Combretaceae do estado da Paraíba; Marquete (2006) elaborou um checklist das Combretaceae da Região Nordeste reconhecendo a ocorrência de 25 espécies e cinco gêneros; Louzada (2013) descreveu as espécies de Combretaceae para a flora de Sergipe; Soares Neto et al. (2014) e Ribeiro et al. (no prelo) realizaram o levantamento florístico da família para os estados do Ceará e Pernambuco, respectivamente, reconhecendo 17 espécies e cinco gêneros para cada estado.

Entre os estados do Nordeste, o Rio Grande do Norte (RN) é considerado o estado com menor riqueza de espécies de angiospermas (Forzza et al. 2010; BFG 2015). No entanto, estudos recentes têm mostrado o quanto à diversidade florística do estado está subestimada, com a descoberta de dezenas de novos registros (e.g., Melo et al. 2008; Ferreira et al. 2009; Queiroz \& Loiola 2009; Almeida Jr. \& Zickel 2011; Lourenço \& Barbosa 2012; Rocha et al. 2012; Versieux et al. 2013a,b; São-Mateus et al. 2013; Costa-Lima et al. 2014; Magalhães et al. 2014; Versieux et al. 2017).

As informações existentes sobre Combretaceae no Rio Grande do Norte são pontuais, com apenas quatro espécies referidas em levantamentos florísticos (e.g., Freire 1990; Maracajá et al. 2003; Assis \& Maracajá 2007;
Santana et al. 2009; Bessa \& Medeiros 2011). No entanto, o BFG (2015) indica a ocorrência de seis espécies reunidas em quatro gêneros no RN [Buchenavia tetraphylla (Aubl.) R.A. Howard, Combretum glaucocarpum Mart., C. lanceolatum Pohl ex Eichler, C. leprosum Mart., Conocarpus erectus L. e Terminalia glabrescens Mart.], número consideravelmente inferior ao do presente trabalho. Os números aqui encontrados contrastam com os que estão listados na Lista de Espécies da Flora do Brasil (BFG 2015; Flora do Brasil 2020 em construção) em virtude da amostragem aqui empregada e por incluirmos a revisão de pequenos herbários pouco visitados por especialistas. Esses novos resultados e ocorrências serão incorporados à Flora do Brasil 2020.

O presente estudo tem por objetivo descrever as espécies de Combretaceae ocorrentes no estado do Rio Grande do Norte, contribuindo para um maior conhecimento da flora local e atualizando a distribuição geográfica dos táxons. Além disso, apresentar uma chave de identificação atualizada, a descrição, distribuição geográfica, e comentários taxonômicos e ilustrações das espécies visando auxiliar no reconhecimento dos táxons.

\section{Material e Métodos}

Área de estudo

Com uma extensão de $53.077,3 \mathrm{~km}^{2}$, o estado do Rio Grande do Norte está dividido em 167 municípios e localiza-se na Região Nordeste do Brasil, limitando-se com os estados do Ceará a oeste, ao sul com a Paraíba, e a leste e ao norte com o Oceano Atlântico (Brasil Channel 2017; Figs. 1;2). Apresenta relevo plano, com depressão na parte central e na porção sul, extensão do planalto da Borborema (Portal Brasil 2009). A vegetação está representada por Savana-Estépica (Caatinga), Savana (Cerrado), Floresta Ombrófila Densa, Floresta Estacional Semidecidual, Floresta Estacional Decidual e Áreas das Formações Pioneiras (Manguezal e Restinga) (IBGE 2012).

\section{Análise morfológica}

Este tratamento taxonômico baseou-se na análise comparativa de espécimes depositados nos herbários ASE, EAC, FUEL, HEPH, HST, HUEFS, IPA, JPB, MAC, MBM, MOSS, NY, UEC e UFRN, cujas siglas estão de acordo com Thiers, continuamente atualizado. As identificações foram realizadas com auxílio de chaves analíticas, consulta à literatura especializada (Marquete 


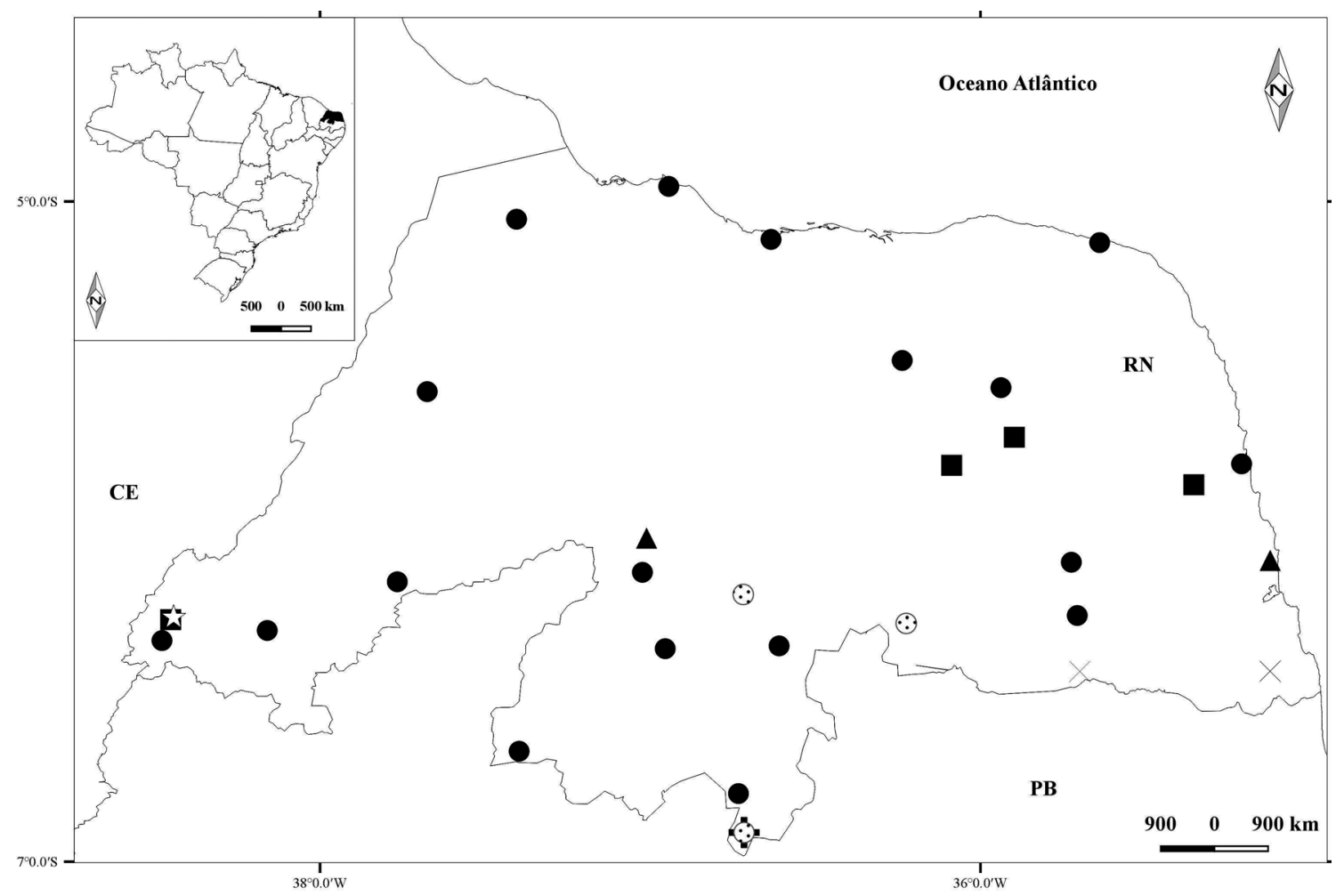

Figura 1 - Distribuição de Combretum no estado do Rio Grande do Norte, Brasil. ( $\mathbf{\square}=$ Combretum duarteanum; $\mathbf{\Delta}=$ C. fruticosum $; \boldsymbol{t}=$ C. glaucocarpum $;+=$ C. hilarianum $; \mathbf{X}=$ Combretum lanceolatum; $\boldsymbol{O}$. leprosum; : $=$ C. monetaria).

Figure 1 - Distribution of Combretum in Rio Grande do Norte state, Brazil. $(\mathbf{\square}=$ Combretum duarteanum; $\boldsymbol{\Delta}=$ C. fruticosum; $\vec{i}=$ C. glaucocarpum $;+=$ C. hilarianum $; \mathbf{x}=$ Combretum lanceolatum; $\mathbf{O}=$ C. leprosum; $;=$ C. monetaria $)$.

1995; Loiola \& Sales 1996; Marquete et al. 2003; Linsingen et al. 2009; Loiola 2009a; Loiola et al. 2009; Stace 2010; Soares Neto et al. 2014) ou por comparação de imagens das coleções-tipo, disponíveis online nos sítios dos herbários BM, BR, G, K, LE, M, MO, OXF, P, PRC, SP, SPSF, TCD, W e WIS ou espécimes previamente identificadas por especialistas nos acervos dos herbários EAC, UFRN e MOSS.

As descrições foram baseadas principalmente em exemplares coletados no Rio Grande do Norte; no entanto, quando as amostras apresentavam apenas flor ou fruto, foram usados materiais adicionais. Para cada gênero foi adotado um padrão próprio de descrição. A terminologia para a descrição dos caracteres morfológicos seguiu Radford et al. (1974) e a dos frutos Barroso et al. (1999). Os nomes dos autores das espécies estão baseados naqueles disponíveis no The International Plant Name Index (IPNI 2017).

Dados referentes à forma de crescimento, habitat, período de floração e frutificação, cor das flores e dos frutos, e nomes populares foram obtidos dos rótulos das exsicatas analisadas. A lista de exsicatas examinadas segue a ordem de apresentação: coletor, número de coleta e espécie segundo a apresentação no texto. Ressalta-se que apenas as espécies nativas de Combretaceae foram alvo de descrições neste estudo. A ocorrência de Combretum indicum (L.) Jongkind e Terminalia catappa L. foi registrada e incluída na chave de identificação e feito também um comentário sobre a distribuição geográfica e das características morfológicas, mas por serem espécies exóticas naturalizadas suas descrições não estão detalhadas aqui.

\section{Distribuição geográfica}

Os mapas de distribuição das espécies foram gerados através do programa Quantum GIS 2.16.0 (QGIS 2017). Quando as coordenadas geográficas associadas à localidade das coletas estavam ausentes nas etiquetas das exsicatas, utilizou-se as coordenadas do município obtidas a partir da ferramenta geoLoc (CRIA 2017). 


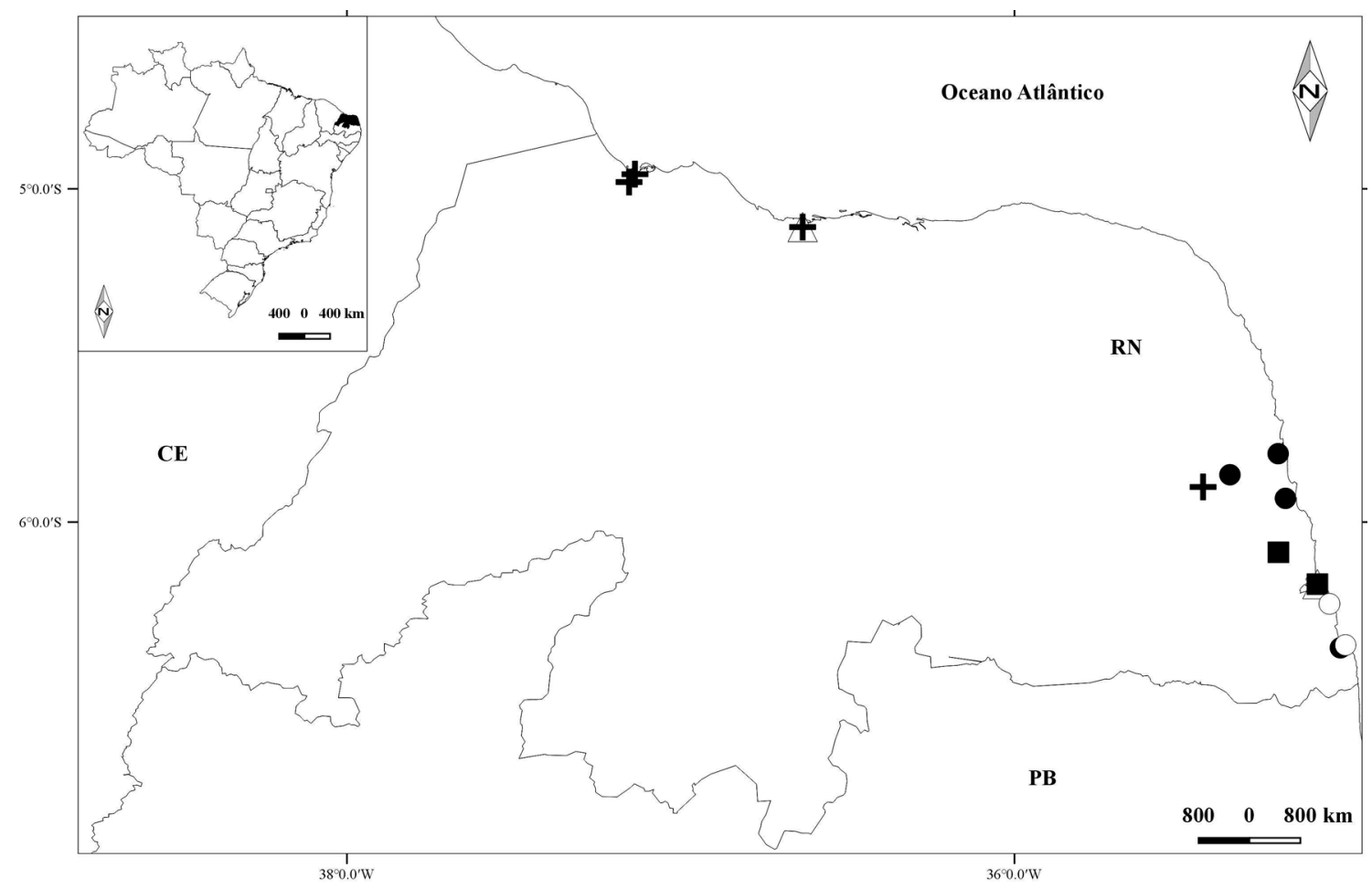

Figura 2 - Distribuição de Buchenavia, Conocarpus, Laguncularia e Terminalia no estado do Rio Grande do Norte, Brasil. ( $=$ Buchenavia tetraphylla; $\Delta=$ Conocarpus erectus $;+=$ Laguncularia racemosa; $\square=$ Terminalia amazonia; $\bigcirc=T$. mameluco).

Figure 2 - Distribution of Buchenavia, Conocarpus, Laguncularia and Terminalia in Rio Grande do Norte state, Brazil. ( $\bullet=$ Buchenavia tetraphylla; $\Delta=$ Conocarpus erectus $;+=$ Laguncularia racemosa $; \mathbf{\square}=$ Terminalia amazonia $; \bigcirc=$ T. mameluco).

\section{Resultados e Discussão}

Para o Rio Grande do Norte foram registradas 12 espécies distribuídas em cinco gêneros, das quais três são novas ocorrências para o estado (indicadas com asterisco): Buchenavia tetraphylla (Aubl.) R. A. Howard, *Combretum duarteanum Cambess., ${ }^{*}$ C. fruticosum (Loefl.) Stuntz, C. glaucocarpum Mart., C. hilarianum D. Dietr., C. lanceolatum Eichler, C. leprosum Mart., C. monetaria Mart., Conocarpus erectus L., Laguncularia racemosa (L.) C.F. Gaertn., *? Terminalia cf. amazonia (J.F. Gmel) Exell e *T. mameluco Pickel. As espécies Combretum glaucocarpum e C. hilarianum, Terminalia cf. amazonia e T. mameluco são espécies pouco coletadas no estado do Rio Grande do Norte.

Quanto aos tipos de vegetação, verificou-se que os representantes de Combretaceae podem ser divididos em dois grupos: os que ocorrem no domínio da Mata Atlântica (Conocarpus erectus: registrado exclusivamente no Manguezal; Terminalia amazonia: Restinga; T. mameluco:
Floresta Ombrófila Densa; Laguncularia racemosa: Manguezal e Restinga; Buchenavia tetraphylla: Floresta Ombrófila Densa e Restinga) e os que têm registro no domínio das Caatingas (Combretum lanceolatum, C. leprosum, C. duarteanum, $C$. fruticosum, C. hilarianum, C. leprosum, $C$. fruticosum e C. monetaria).

Apenas quatro espécies foram registradas em cinco unidades de conservação do estado, indicando que a conservação da família como um todo no Rio Grande do Norte encontra-se vulnerável: Estação Ecológica do Seridó (Combretum leprosum), Parque Estadual das Dunas (Buchenavia tetraphylla e C. leprosum), Reserva Particular do Patrimônio Nacional (RPPN) Mata Estrela (Buchenavia tetraphylla, Terminalia mameluco) e RPPN Stoessel de Brito (C. fruticosum e C. leprosum).

\section{Tratamento taxonômico}

Combretaceae R. Br., Prodr. 351. 1810.

Árvores, arbustos ou lianas, heliófilas, xerófilas ou halófilas. Folhas opostas ou 
alternas, espiraladas ou verticiladas, simples, inteiras, pecioladas, sem estípulas; lâmina foliar membranácea, cartácea, subcoriácea ou coriácea, elíptica, ovada, obovada, oblanceolada, lanceolada ou oblonga. Inflorescências axilares ou terminais, espigas, panículas de espigas, capítulos ou racemos subcapitados. Flores 4-5-meras, actinomorfas ou zigomorfas, monoclamídeas ou diclamídeas; hipanto envolvendo o ovário, expandido para a parte superior; lobos do cálice 4-5, simétricos; pétalas 4-5 ou ausentes, pequenas ou conspícuas, alternissépalas; androceu diplostêmone, 4-10, em 2 verticilos, estames exsertos, filiformes, subulados ou truncados; anteras dorsifixas, versáteis ou adnatas aos filetes, rimosas; disco nectarífero desenvolvido ou inconspícuo na base do hipanto superior; ovário ínfero, unilocular, 2-6 óvulos, apicais, placentação pêndula. Frutos indeiscentes, drupoides, nucoides ou betulídios, 2-5 alas; semente 1, sem endosperma, cotilédones convolutos ou plicados.

\section{Chave de identificação dos gêneros de Combretaceae ocorrentes no Rio Grande do Norte, Brasil}

1. Hipanto inferior com 2 bractéolas adnatas na porção distal .... 4. Laguncularia

1'. Hipanto inferior sem bractéolas adnatas.

2. Folhas opostas; pétalas usualmente presentes (ausentes em C. glaucocarpum)...... 2. Combretum

2'. Folhas alternas; pétalas ausentes.

3. Hipanto superior cupuliforme; anteras adnatas aos filetes 1. Buchenavia

3'. Hipanto superior campanulado; anteras versáteis.

4. Inflorescências em capítulos globosos pedunculados; hipanto inferior assimétrico; frutos agregados.... 3. Conocarpus

4'. Inflorescências em espigas ou panículas de espigas; hipanto inferior fusiforme, cilíndrico ou 4-5 anguloso; frutos betulídios 5. Terminalia

1. Buchenavia Eichler, Flora 49: 164. 1866. 1.1. Buchenavia tetraphylla (Aubl.) R.A. Howard, J. Arnold Arbor. 64(2): 266. 1983. Figs. 2; 3a,b Árvores ou arbustos, 4-15 m alt.; ramos acinzentados, estriados, glabros. Folhas alternas, concentradas no ápice dos ramos; pecíolo 3-5 mm compr., sem glândulas na parte distal; lâmina foliar 3-7,5 × 1,3-3,8 cm, obovada ou oblanceolada, base cuneado-atenuada, ápice arredondado ou emarginado, glabra em ambas as faces; nervação broquidódroma. Inflorescências axilares ou terminais, em capítulos densifloros, 0,5-1 cm compr., pedúnculo 1,8-2,3 cm compr.; bráctea 1 , ca. $1,5 \times 1 \mathrm{~mm}$, cimbiforme, pubescente. Flores 2-3 mm compr., esverdeadas; hipanto inferior ca. 1,2 $\times 0,3 \mathrm{~mm}$, cilíndrico, densamente pubescente; hipanto superior ca. $1 \times 1,6 \mathrm{~mm}$, cupuliforme, glabro; lobos do cálice inconspícuos; pétalas ausentes. Estames 10, exsertos; filetes do verticilo interno $1,4-1,8 \mathrm{~mm}$ compr., filetes do verticilo externo 2-2,3 $\mathrm{mm}$ compr.; anteras $0,3-0,5 \times 0,4-0,6 \mathrm{~mm}$, cordiformes. Disco nectarífero aneliforme, piloso; ovário ca. $0,7 \times$ 0,3 mm; estilete ca. $1 \mathrm{~mm}$ compr., linear, glabro; estigma truncado. Fruto 1,3-2,4 × 0,2-1,1 cm, drupáceo, oval-elíptico, pontiagudo no ápice, glabro, levemente costado.
Material examinado: Baía Formosa, RPPN Mata Estrela, 6²2'40"S, 35¹'22"W, 1.V.2012, fr., J.G. Jardim et al. 6255 (EAC, JPB, NY, UFRN). Macaíba, Colégio Agrícola de Jundiaí, 553'30”S, 35²1'0”W, 1.III.1999, fr., L.A. Cestaro 99-0097 (UFRN). Natal, Parque Estadual das Dunas, 11.XII.2006, fl., A.V. Melo et al. 01 (UFRN). Parnamirim, 5055'45'S, 35'11'15'W, 10.IX.1999, fr., L.A. Cestaro 99-0190 (IPA, UFRN).

Buchenavia tetraphylla é facilmente reconhecida por apresentar hipanto inferior cilíndrico e o superior cupuliforme com lobos do cálice inconspícuos, anteras cordiformes e fruto drupáceo. Espécie distribuída na região Neotropical, ocorrendo desde Cuba até o Brasil (Weaver 1991; Stace 2010). No Brasil está registrada para as regiões CentroOeste, Norte, Nordeste e Sudeste; nesta última região a ocorrência de $B$. tetraphylla limita-se ao sul do Espírito Santo (BFG 2015). No Rio Grande do Norte, foi registrada em vegetação de Floresta Ombrófila Densa e Restinga (Fig. 2). De acordo com Weaver (1991), B. tetraphylla é uma espécie utilizada como ornamental. Coletada com flores em dezembro e frutos entre os meses de março e setembro. Conhecida popularmente como "mirindiba".

2. Combretum Loefl. Iter Hispan. 308. 1758.

Árvores, arbustos ou subarbustos, eretos ou escandentes ou lianas. Folhas simples, opostas, com 

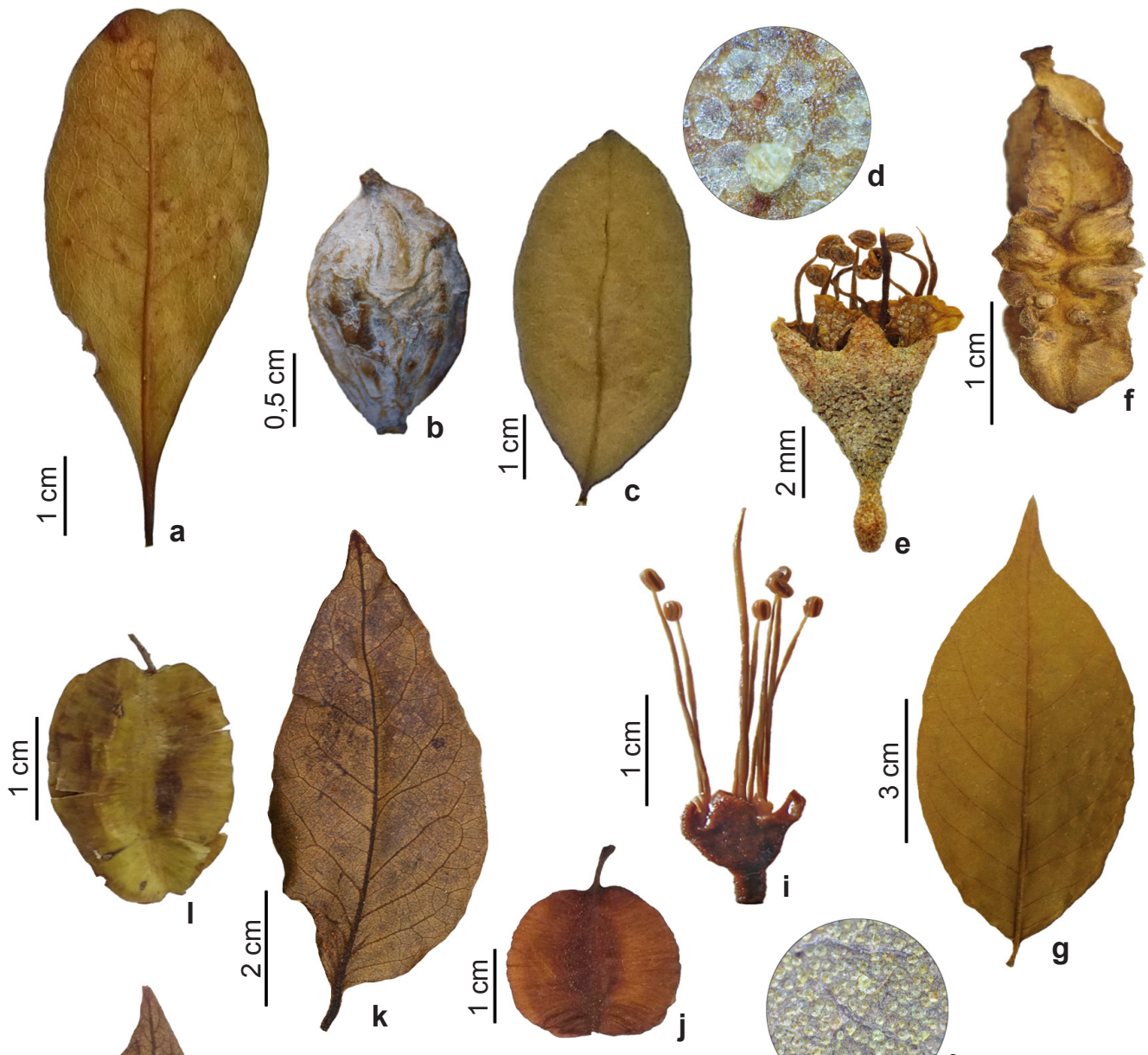

$\varepsilon$
ำ
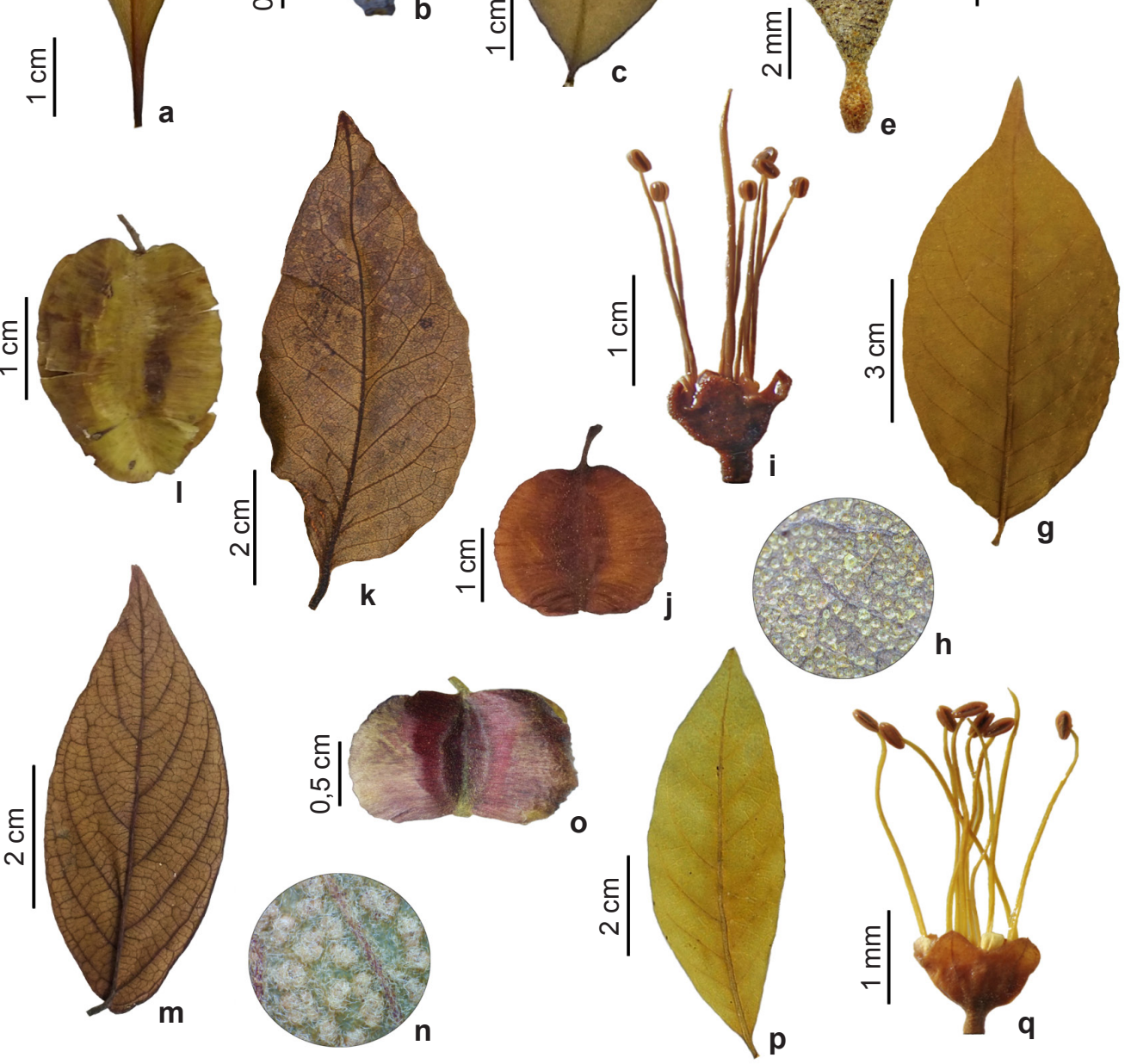

h

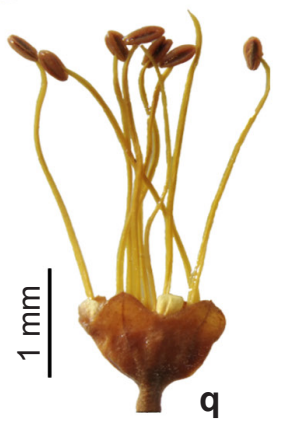

Figura 3 - a,b. Buchenavia tetraphyla - a. folha; b. fruto. c-f. Combretum duarteanum - c. folha; d. detalhe dos tricomas lepidotos na face abaxial da folha; e. flor; f. fruto. g-j. C. fruticosum - g. folha; h. detalhe dos tricomas lepidotos na face abaxial da folha; i. flor; j. fruto. k,1. C. glaucocarpum - k. folha; 1. fruto. m-o. C. hilarianum - m. folha; n. detalhe dos tricomas lepidotos na face abaxial da folha; o. fruto. p,q. C. lanceolatum - p. folha; q. flor. (a,b. J.G. Jardim et al. 6255; c-f. E.C. Tomaz et al. 27; g-i. R.C. Oliveira et al. 1738; j. P. Bezerra 301; k. A.C. Sarmento 749; 1. M.A.P. Silva 4735; m-o. V.F. Sousa et al. 28; p,q. R.L. Soares-Neto 108).

Figure 3 - a,b. Buchenavia tetraphyla - a. leaf; b. fruit. c-f. Combretum duarteanum - c. leaf; d. detail of lepidote trichomes on the abaxial surface of leaf; e. flower; f. fruit. g-j. C. fruticosum - g. leaf; h. detail of lepidote trichomes on the abaxial surface of leaf; i. flower; $j$. fruit. k,l. C. glaucocarpum - k. leaf; 1. fruit. m-o. C. hilarianum - m. leaf; $n$. detail of lepidote trichomes on the abaxial surface of leaf; o. fruit. p,q. C. lanceolatum - p. leaf; q. flower. (a,b. J.G. Jardim et al. 6255; c-f. E.C. Tomaz et al. 27; g-i. R.C. Oliveira et al. 1738; j. P. Bezerra 301; k. A.C. Sarmento 749; 1. M.A.P. Silva 4735; m-o. V.F. Sousa et al. 28; p,q. R.L. Soares-Neto 108). 
tricomas lepidotos em ambas as faces (tomentosoviloso em $C$. hilarianum). Inflorescências em espigas, racemos ou panículas, axilares e/ou terminais; bractéolas lineares, estreito-lineares, elípticas, estreito-ovais, obovadas, espatuladas ou estreito-espatuladas. Flores hermafroditas, raramente unissexuadas. Hipanto inferior aderente ao ovário, sem bractéolas adnatas; hipanto superior em tubo curto ou comprido. Lobos do cálice 4; pétalas 4 , inseridas na fauce do hipanto superior, entre os lobos do cálice ou raramente ausentes. Estames (4-)8-10, exsertos, inseridos em dois verticilos; anteras versáteis, rimosas. Disco nectarífero aneliforme, cônico ou infundibuliforme. Estigma truncado ou obtuso; ovário com 2-6 óvulos. Fruto betulídio, elíptico a largo elíptico, oblongo-elíptico, orbicular ou obovado, 4-alado; alas planas (plicadas em C. duarteanum).

Combretum abrange 255 espécies distribuídas nas regiões tropicais e subtropicais da África, Ásia e Américas Central e do Sul (Stace 2010). Para o Brasil estão registradas 22 espécies, das quais três são endêmicas e 12 ocorrem na região Nordeste (BFG 2015). No presente estudo foram registradas sete espécies de Combretum para o estado do Rio Grande do Norte.

\section{Chave de identificação das espécies de Combretum no Rio Grande do Norte}

1. Flores sem pétalas; estames 4, inclusos

2.3. Combretum glaucocarpum

1'. Flores com pétalas; estames 8, exsertos.

2. Flores 30-45 mm compr.; hipanto superior estreitamente tubiforme.... 2.5. Combretum indicum

2'. Flores 2,8-20 mm compr.; hipanto superior não tubiforme.

3. Porções reprodutivas e vegetativas densamente cobertas por indumento tomentoso-viloso e poucos tricomas lepidotos. 2.4. Combretum hilarianum

3'. Porções reprodutivas e vegetativas densamente cobertas apenas por tricomas lepidotos.

4. Bractéola linear a estreito-oval.

5 Hipanto inferior 1,5-2 mm compr., elíptico a ovoide; hipanto superior 2-2,5 mm compr., cupuliforme; pétalas espatuladas ou obovadas.

2.8. Combretum monetaria

5'. Hipanto inferior 2-2,2 mm compr., fusiforme; hipanto superior 4-5 mm compr., alongado-campanulado; pétalas orbiculares.

2.7. Combretum leprosum

4'. Bractéola espatulada, estreito-espatulada ou obovada.

6. Frutos com alas plicadas (anfractuoso-plicado); pedicelo frutífero 10-30 mm compr.

2.1. Combretum duarteanum

6'. Frutos com alas planas; pedicelo frutífero 2-6 $\mathrm{mm}$ compr.

7. Tricomas lepidotos esbranquiçados a amarelados nas partes vegetativas e reprodutivas; hipanto inferior 6-7 $\mathrm{mm}$ compr., tetrágono; hipanto superior 4-6 mm compr., crateriforme; disco nectarífero cônico

2.6. Combretum lanceolatum

7'. Tricomas lepidotos amarelados a ferrugíneos nas partes vegetativas e reprodutivas; Hipanto inferior 4-6 mm compr., fusiforme a tetrágono; hipanto superior ca. $5 \mathrm{~mm}$ compr., infundibuliforme-campanulado; disco nectarífero aneliforme. 2.2. Combretum fruticosum

2.1. Combretum duarteanum Cambess., Fl. Bras. Merid. (A. St.-Hil.) 2: 248. $1829 . \quad$ Figs. 1; 3c-f

Arvoretas ou arbustos com ramos escandentes a lianescentes, 2,5-5 $\mathrm{m}$ alt., densamente recobertos por tricomas lepidotos hialinos ou ferrugíneos nas porções vegetativas e reprodutivas; caule e ramos acinzentados. Folha 5-8 × 2,5-4,5 cm, membranácea, elíptica a largo-elíptica, ápice agudo ou acuminado, base cuneada; nervação eucamptódroma-broquidódroma, 6-8 pares de nervuras secundárias; pecíolo 2-3 $\mathrm{mm}$ compr. Inflorescências 3,5-4,0 cm compr., racemos paucifloros, axilares. Bractéola 1, ca. 1,5 ×0,5 mm, espatulada; botão floral 2-3 × 1-1,5 mm, turbinado. Flores ca. $8 \times 3 \mathrm{~mm}$, amareladas; hipanto inferior ca. $2 \times 0,8 \mathrm{~mm}$, fusiforme a levemente tetrágono, densamente lepidoto; hipanto superior 1,5-2 × 2 $\mathrm{mm}$, cupuliforme; lobos do cálice ca. $1 \times 0,5 \mathrm{~mm}$, 
deltoides; pétalas ca. 1,5-2 ×0,5 mm, estreitoespatuladas, amareladas a avermelhadas. Estames 8, exsertos; filetes do verticilo interno ca. $3 \mathrm{~mm}$ compr., filetes do verticilo externo 3,5 mm compr.; anteras ca. $0,5 \times 0,3 \mathrm{~mm}$, elípticas; disco nectarífero $0,5 \mathrm{~mm}$ compr., aneliforme, margem livre, viloso; ovário ca. $0,8 \times 0,6 \mathrm{~mm}$; estilete ca. $3,5 \mathrm{~mm}$ compr., filiforme; estigma truncado. Fruto 2,5-3 × 0,8-1, 1 $\mathrm{cm}$, elíptico ou obovado, anfractuoso-plicado; alas 2,5-3,9 × 2-3,5 mm, sinuosas, estreitas; pedicelo frutífero $1-3 \mathrm{~cm}$ compr.

Material examinado: Bento Fernandes, Serra da Cachoeira do Sapo, 5'42'51's, 35'53'51'W, 266 m, 8.II.2012, fl., J.L. Costa-Lima et al. 617 (UFRN). Caiçara do Rio do Vento, Serra da Ubaia, 5\%47'58"S, 36 5'15'W, 424 m, 30.X.2014, fl., A.A. Roque 1570 (UFRN). Coronel João Pessoa, 6¹6'1'S, 38²7'9"W, 418 m, 19.IV.2015, fl. e fr., E.C. Tomaz et al. 27 (UFRN). Macaíba, Escola Agrícola de Jundiaí, 15.IX.2015, fr., V.F. Sousa 86 (UFRN).

Combretum duarteanum caracteriza-se pelo hipanto superior cupuliforme, pétalas estreitoespatuladas e frutos anfractuoso-plicados com alas sinuosas. É uma espécie exclusiva da América do Sul, ocorrendo na Bolívia, Brasil e Paraguai (Marquete 1995; Stace 2010). No Brasil, há registros para as regiões Centro-Oeste, Nordeste, Norte e Sudeste (BFG 2015). No Rio Grande do Norte, foi coletada em vegetação de SavanaEstépica (Fig. 1). Coletada com flores de fevereiro a outubro e frutos em abril, sendo aqui referida pela primeira vez para o estado.

2.2. Combretum fruticosum (Loefl.) Stuntz, Invent. Seeds U.S.D.A. Bur. P1. Industr. 31: 86. 1914.

Figs. $1 ; 3 \mathrm{~g}-\mathrm{j}$

Arbustos ou lianas, até $3 \mathrm{~m}$ de alt., densamente recobertos por tricomas lepidotos amarelados a ferrugíneos peltados nas porções vegetativas e reprodutivas; caule e ramos castanhoavermelhados. Folhas 3-10 × 1,5-6,7 cm, coriácea, estreito-elíptica a elíptica, ápice acuminado a arredondado; base aguda, glabra na face abaxial e pilosa na adaxial, com tricomas mais concentrados na nervura primária; nervação geralmente eucamptódroma-boquidódroma, às vezes eucamptódroma ou broquidódroma, 5-10 pares de nervuras secundárias; pecíolo 3-4 mm compr. Inflorescências 5-14,5 cm compr., racemos densifloros, axilares ou terminais. Bractéola 1, com 1-2 mm compr., estreito-espatulada; botão floral 8-9 mm compr., turbinado. Flores subsésseis ca. 20 mm compr., avermelhadas; hipanto inferior 4-6 $\times$ 0,4-0,5 mm, fusiforme a tetrágono; hipanto superior ca. $5 \times 4 \mathrm{~mm}$, infundibuliforme-campanulado; lobos do cálice 1-1,5 × 1-1,2 mm, deltoides; pétalas ca. 1,5 ×0,5 $\mathrm{mm}$, elípticas, menores que os lobos do cálice, amareladas. Estames 8, exsertos; filetes do verticilo interno 12-13 mm compr., filetes do verticilo externo 13-14 mm compr.; anteras ca. $0,5 \times 0,5 \mathrm{~mm}$, elípticas; disco nectarífero conspícuo, aneliforme, margem livre, densamente viloso; ovário ca. 1,5-1,7 × 0,4-0,5 mm; estilete 1,3-1,4 cm compr.; estigma truncado. Fruto 1,4-2 $\times 1,4-2,2 \mathrm{~cm}$, elíptico; alas 1,4-2,1 ×0,4-0,6 cm, planas; pedicelo frutífero $0,2-0,3 \mathrm{~cm}$ compr.

Material examinado: Jucurutu, RPPN Stoessel de Britto, 27.I.2008, fl., A.A. Roque 424 (JPB, UFRN). Nísia Floresta, 16.VII.2006, fl., R.C. Oliveira et al. 1738 (ASE, EAC, HUEFS, MOSS, UFRN).

Material adicional: BRASIL. CEARÁ: Pacoti, Serra de Baturité, Sítio Germinal, 30.VIII.1941, fr., P. Bezerra 301 (EAC).

Combretum fruticosum distingue-se das demais espécies do gênero por possuir hipanto inferior fusiforme a tetrágono e hipanto superior infundibuliforme-campanulado, pétalas elípticas, disco nectarífero aneliforme e tricomas lepidotos amarelados a ferrugíneos peltados recobrindo caules, folhas, botões, flores e frutos. Trata-se de uma espécie amplamente distribuída no Neotrópico, ocorrendo desde o México até a Argentina (Stace 2010). Segundo Linsingen \& Cervi (2008), $C$. fruticosum é uma espécie polimórfica e heliófita. No território brasileiro, até o presente trabalho, apenas para o Rio Grande do Norte não era citada (BFG 2015). Constitui, portanto, o primeiro registro para o estado, onde foi encontrada em vegetação de Savana-Estépica e na transição de Restinga e Floresta Ombrófila Densa. Coletada com flores em janeiro e julho.

2.3. Combretum glaucocarpum Mart., Flora 24(2, Beibl.): 3. 1841.

Figs. 1; 3k,1

Árvores, 5-8 m de alt., densamente recobertas por tricomas lepidotos hialinos ou amarelados nas porções vegetativas e reprodutivas; ramos castanhoavermelhados. Folhas 5-9 × 2,5-4,1 cm, coriácea, elíptica, ápice acuminado, base aguda; nervação eucamptódroma a eucamptódroma-broquidódroma, 5-8 pares de nervuras secundárias; pecíolo 2,2-5,2 mm compr. Inflorescências 1,3-3 cm compr., em racemos densifloros, axilares ou terminais. Bractéola 1, com 1-2 mm compr., estreito-espatulada; botão floral 2-3 mm compr., turbinado. Flores subsésseis 3,5-4 mm compr., avermelhadas; hipanto inferior $1-1,5 \times 0,5-0,6 \mathrm{~mm}$, fusiforme a tetrágono; hipanto superior 2-3 × 1,5-2,5 mm, campanulado; lobos 
do cálice ausentes ou 4, muito curtos, deltoides, avermelhados; pétalas ausentes; estames 4, inclusos, todos do mesmo tamanho; filetes 1,5-2 mm compr.; anteras ca. 0,5 × 0,5 mm, elípticas, avermelhadas; disco nectarífero conspícuo, aneliforme, margem livre, densamente viloso; ovário $0,5-1 \times 0,4-0,5$ mm compr.; estilete 13-14 mm compr.; estigma plano. Fruto $16-21 \times 20-24 \mathrm{~mm}$, elíptico a largo elíptico; alas $14-15 \times 6-8 \mathrm{~mm}$, planas, escariosas; pedicelo frutífero $21-23 \mathrm{~mm}$ compr.

Material examinado: Coronel João Pessoa, topo da Serra de São José, 7.V.1984, bot., A.C. Sarmento 749 (MBM, NY).

Material adicional: BRASIL. CEARÁ: Crato, Av. Pedro Felício Cavalcante, 17.VIII.2008, fr., M.A.P. Silva 47359 (EAC). Novo Oriente, Morro dos Três Irmãos, 20.II.1989, fl., F.S. Araújo (EAC 15728).

Combretum glaucocarpum é uma espécie bem definida, que se caracteriza por possuir flores diminutas (3,5-4 mm compr.), com hipanto superior campanulado, lobos do cálice ausentes ou 4, muito curtos e pétalas ausentes. Ocorre no Brasil, Bolívia e Peru (Stace 2010). Para o Brasil, a espécie está registrada nas regiões Norte, Nordeste e Sudeste (BFG 2015). No Rio Grande do Norte, está representada por apenas uma coleta e foi registrada em vegetação de Savana-Estépica (Fig. 1). Coletada com botões no mês de maio. Conhecida popularmente como "sipaúba" (A.C. Sarmento 749).

2.4. Combretum hilarianum D. Dietr., Syn. P1. 2: 1303.1840 .

Figs. 1; 3m-o

Arbustos escandentes, 3-3,5 m alt., densamente recobertos por indumento tomentosoviloso, amarelado a ferrugíneo e poucos tricomas lepidotos nas porções vegetativas e reprodutivas; ramos avermelhados. Folhas 5,9-7,7 × 2,3-3 cm, subcoriácea, estreito-elíptica a elíptica, ápice agudo ou acuminado, base cordada ou obtusa; nervação eucamptódroma a eucamptódroma-broquidódroma, 6-9 pares de nervuras secundárias; pecíolo 3-5 mm compr. Inflorescências 5,5-6 cm compr., racemos, densifloros, axilares ou terminais. Bractéola 1, com 0,5-1 × 0,6-0,8 mm, elíptica; botão floral 2,8-3 $\times 1,3-1,8 \mathrm{~mm}$, elíptico-arredondado. Flores $6-7 \times$ 3-4 mm, esverdeadas; hipanto inferior 1,8-2,2 $\times$ 0,9-1,1 mm, fusiforme; hipanto superior 1,8-2,2 $\times 2,8-3,1 \mathrm{~mm}$, cupuliforme a campanulado; lobos do cálice ca. $2 \times 1 \mathrm{~mm}$, deltoides; pétalas $1-1,2 \times$ 0,8-1 mm, obovadas. Estames 8, exsertos; filetes do verticilo interno 2,5-3,2 $\mathrm{mm}$ compr., filetes do verticilo externo 3-3,5 mm compr.; anteras $0,6 \times$ $0,5 \mathrm{~mm}$, cordiformes; disco nectarífero 0,5-1 mm compr., aneliforme, margem livre, densamente viloso; ovário ca. $1 \times 0,5 \mathrm{~mm}$; estilete $2,5-3 \mathrm{~mm}$ compr., filiforme; estigma truncado. Fruto 1-1,4 $\times 0,8-1,4 \mathrm{~cm}$, oblongo-elíptico, vináceo quando jovem e castanho na maturidade; alas $0,8-1,3 \times$ 0,3-0,5 mm, planas; pedicelo frutífero $0,2-0,5$ cm compr.

Material examinado: Equador, Serra das Queimadas, área para instalação do Complexo Eólico Santapape, 6 54'43”'S, 3642'58'W, 13.VIII.2015, fl. e fr., V.F. Sousa et al. 28 (UFRN).

Combretum hilarianum é facilmente reconhecida pelo hábito escandente, por apresentar indumento tomentoso-viloso e poucos tricomas lepidotos recobrindo as porções vegetativas e reprodutivas e pétalas obovadas. É uma espécie sul-americana distribuída na Bolívia, Brasil, Paraguai e Peru (Stace 2010). Em território brasileiro, C. hilarianum está distribuída nas regiões Centro-Oeste, Norte, Nordeste e Sudeste, desenvolvendo-se na Amazônia, Caatinga e Cerrado (BFG 2015). No Rio Grande do Norte, foi coletada em vegetação de Savana-Estépica (Fig. 1). Coletada com flores e frutos em agosto. Moura et al. (2018) citaram sua ocorrência no município de Equador, Rio Grande do Norte.

2.5. Combretum indicum (L.) Jongkind, Fl. Gabon 35: 48.1999.

Comentários: nativa da Ásia Tropical (Acevedo-Rodríguez 2005) e cultivada como ornamental no Caribe, nas Américas Central e do Sul (Stace 2010). Em território brasileiro, C. indicum está citada nas regiões Norte (Pará), Nordeste (Bahia, Ceará, Pernambuco), CentroOeste (Distrito Federal, Mato Grosso) e Sudeste (Minas Gerais) (BFG 2015). A espécie apresenta caracteres distintivos como inflorescências em racemos de espigas, flores grandes $(30-50 \mathrm{~mm}$ de comprimento), hipanto superior estreitamente tubiforme e estilete adnato a parede interna do hipanto inferior.

Material examinado: Mossoró, $5^{\circ} 11$ ' 15 "S, 37²0'39'W, 10.XII.1995, fl., T. Paiva 9 (MOSS).

2.6. Combretum lanceolatum Pohl ex Eichl., Fl. Bras. (Martius) 14(2): 110, pl. 28, 34, f. 4.1867.

Figs. 1; 3p,q

Arvoretas a arbustos escandentes, 4-6 $\mathrm{m}$ alt., densamente recobertos por tricomas lepidotos esbranquiçados a amarelados nas porções vegetativas e reprodutivas. Folhas 7-10 $\times$ 3,5-5,7 cm, subcoriácea, estreito-elíptica a elíptica, ápice agudo a acuminado, base aguda; 
nervação eucamptódroma-boquidódroma, 6-8 pares de nervuras secundárias; pecíolo 2-8 mm compr. Inflorescências 6,5-16 cm compr., panículas de racemos, densifloras, axilares ou terminais. Bractéola 1, ca. $3 \mathrm{~mm}$ compr., obovada a espatulada; botão floral 8-10 mm compr., turbinado. Flores subsésseis 2,8-3,2 $\mathrm{mm}$ compr., amareladas; hipanto inferior 6-7 $\times$ $1 \mathrm{~mm}$, tetrágono; hipanto superior 4-6 × 5-6 $\mathrm{mm}$, crateriforme, externamente lepidoto e internamente pubescente; lobos do cálice 1,8-2,1 $\times 2,5-3 \mathrm{~mm}$, deltoides; pétalas ca. 1,5 × 1,2 mm, suborbiculares a orbiculares, menores que os lobos do cálice, creme. Estames 8, exsertos; filetes do verticilo interno $1,7-1,9 \mathrm{~cm}$ compr., filetes do verticilo externo 18-2 mm compr; anteras ca. $1,3 \times 1 \mathrm{~mm}$, elípticas; disco nectarífero cônico, velutino, envolvendo o estilete, margem livre; ovário ca. $0,9-1 \times 0,4-0,6 \mathrm{~mm}$; estilete $2,6-2,8 \mathrm{~cm}$ compr., filiforme; estigma truncado. Fruto 16,5-19 $\times 13,5-14 \mathrm{~mm}$, elíptico; alas $15-17 \times 3-5 \mathrm{~mm}$, planas; pedicelo frutífero 4-6 $\mathrm{mm}$ compr.

Material examinado: Baía Formosa, Sagi, 6²5'24”S, 35'7'21'W, 2.VIII.2014, fl., R.L. Soares-Neto 108 (UFRN). Serra de São Bento, Pedra do Cruzeiro, 6'25'28'S, 3541'57''W, 25.VIII.2012, fl., B. Colombo et al. 6 (UFRN).

Material adicional: BRASIL. CEARÁ: granja, à beira de um riacho, 20.X.1988, fr., M. Andrade Neto (EAC 15776).

Combretum lanceolatum distingue-se das demais espécies por apresentar hipanto superior crateriforme, pétalas suborbiculares a orbiculares, disco nectarífero protuberante, frutos elípticos (vináceos quando jovens e marrons na maturação) e tricomas lepidotos esbranquiçados a amarelados. A espécie está distribuída exclusivamente na América do Sul ocorrendo na Bolívia, Brasil e Paraguai (Stace 2010). No Brasil, foi registrada nas regiões Centro-Oeste, Norte, Nordeste (maior representatividade) e Sudeste (Marquete 1990; BFG 2015). No Rio Grande do Norte, foi coletada em vegetação de Savana-Estépica e de Restinga. De acordo com Loiola (2009a), esta espécie tem valor econômico no campo da medicina popular, sendo suas cascas utilizadas como adstringentes, e também tem potencial ornamental. Coletada com flores em julho e agosto.

2.7. Combretum leprosum Mart., Flora 24(2, Beibl.): 1. 1841.

Figs. 1; 4a,b

Arvoretas, arbustos escandentes ou lianescentes, 2,5-4 $\mathrm{m}$ alt., densamente recobertos por tricomas lepidotos hialinos ou amarelados nas porções vegetativas e reprodutivas; ramos acinzentados. Folhas 4,5-14,5 × 4-7,6 cm, cartácea a subcoriácea, elíptica a largo-elíptica, ápice agudo, acuminado, base arredondada, nervação eucamptódroma-broquidódroma; pecíolo 5-10 mm compr. Inflorescências 4-10 cm compr., panículas de racemos densifloros, axilares ou terminais. Bractéola 1, com 2-3 $\times 0,3-0,5 \mathrm{~mm}$, linear; botão floral 3,5-5 × 1-2 mm, turbinado. Flores subsésseis 5-8 × 2,2-4 mm, amareladas; hipanto inferior $2-2,2 \times 1-1,2 \mathrm{~mm}$, fusiforme; hipanto superior $4-5 \times 2-2,8 \mathrm{~mm}$, alongadocampanulado; lobos do cálice 1,2-2 × 1-1,4 $\mathrm{mm}$, triangulares; pétalas 1,8-2 × 1-1,2 mm, orbiculares, amarelas. Estames 8, exsertos; filetes do verticilo 3,5-4 mm compr.; anteras 0,5-1 $\times$ 0,3-0,6 mm, elípticas; disco nectarífero ca. 1 mm compr., infundibuliforme, margem não livre, densamente viloso à altura da inserção dos filetes; ovário 1-1,2 × 0,4-0,5 $\mathrm{mm}$; estilete 6-7 $\mathrm{mm}$ compr., filiforme; estigma agudo. Fruto 1,5-2,5 $\times$ 1,5-2,2 cm, largo elíptico; alas 1,5-2,4 ×0,5-0,8 $\mathrm{cm}$, planas; pedicelo frutífero $0,5-1 \mathrm{~cm}$ compr. Material examinado: Acari, 6'20'47'S, 36³6'36"W, 348 m, 26.II.2011, fl., A.B. Jardim et al. 253 (UFRN). Almino Afonso, 21.VI.2003, fr., M.A.G. Paiva 27 (HST, UFRN). Areia Branca, 5'57'16"S, 36 56'39'W, 103 m, 9.IV.2016, fl., E.O. Moura et al 595 (UFRN). Caicó, 6021'18'S, 3657'17'W, 370 m, 15.VIII.2009, fl. e fr., J.G. Jardim et al. 5561 (UFRN). Cerro Corá, 7.IV.2012, fl., A.C. Silva (UFRN 15643). Felipe Guerra, 5'34'34'S, 3740'32”'W, 26.IV.2008, fl., R. C. Oliveira 2137 (MOSS, UFRN). João Câmara, 5³3'51'S, 35'55'77'W, 6.VIII.2012, fl., M.A. Targino \& M.R.O. Trindade 29 (UFRN). Jucurutu, RPPN Stoessel de Britto, 612'36”'S, 37²'38'W, 154 m, 6.IV.2007, fl. e fr., A.A. Roque 33 (UFRN). Macau, 15.V.2008, fl., J.L.C. Lima 19 (UFRN). Marcelino Vieira, 6¹7'59'S, 38'9'36"W, 10.VI.2014, fr., A.F. Silva 92 (UFRN). Mossoró, 12.V.2006, fl., M.L. Silva \& R.C. Oliveira 54 (MOSS, UFRN). Natal, Parque das Dunas, 23.II.1999, fl., A. Trindade (HST 17601, MOSS 12323, UFRN 1813). Parelhas, 18.VIII.2015, fr., A.S. Soares et al. 53 (UFRN). Santana do Seridó, 11.VIII.2015, fr., E.O. Moura 402 (UFRN). São Miguel do Gostoso, 26.VI.2007, fl., G.B.C. Paterno \& M.I.B. Loiola 28 (UFRN). Serra Caiada, 6'5'35"S, 35'43'30”W, 250 m, 28.VI.2016, fr., G.S. Garcia et al. 218 (UFRN). Serra de São Bento, 6¹5'16"S, 35'42'25"W, $200 \mathrm{~m}$ alt., 25.VIII.2012, fr., L.M. Versieux et al. 565 (UFRN). Serra Negra do Norte, Estação Ecológica do Seridó, 16.VII.2005, fr., A. Carrhá (UFRN 2598). Serra Verde, 17.V.1983, fl., A. Trindade (UFRN 222). Venha Ver, Serra de São José, 6¹9'49'S, 38²8'44'W, 678 m, 4.VIII.2010, fr., A.A. Roque 857 (UFRN). 

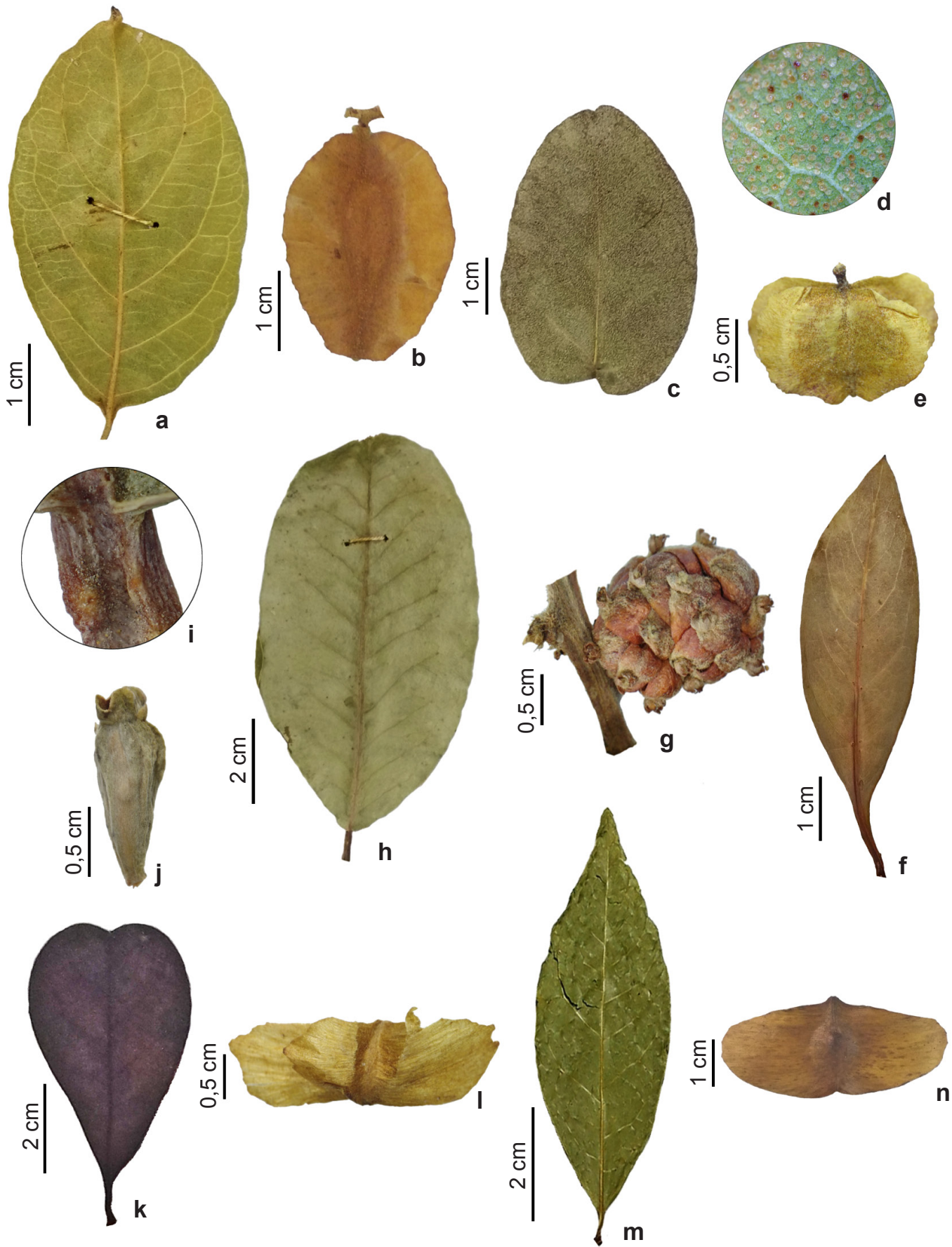

Figura 4 - a,b. Combretum leprosum - a. folha; b. fruto. c-e. C. monetaria - c. folha; d. detalhe dos tricomas lepidotos na face abaxial da folha; e. fruto. f,g. Conocarpus erectus - f. folha; g. inflorescência. h-j. Laguncularia racemosa - h. folha; i. detalhe das glândulas de sal no ápice do pecíolo; j. fruto. k,1. Terminalia amazonia - k. folha; 1 . fruto. m,n. T. mameluco - m. folha; n. fruto. (a,b. E.O. Moura 402; c-e. A.A. Roque 1088; f,g. R.C. Oliveira et al. 1735; h-j. T.A. Barbosa 01; k,1. A. Dantas et al. 178; m,n. R.L. Soares Neto 67).

Figure 4 -a,b. Combretum leprosum - a. leaf; b. fruit. c-e. C. monetaria - c. leaf; d. detail of lepidote trichomes in abaxial surface of leaf; e. fruit. f,g. Conocarpus erectus - f. leaf; g. inflorescence. h-j. Laguncularia racemosa - h. leaf; i. detail of stalk glands on the apex of the petiole; j. fruit. k,l. Terminalia amazonia - k. leaf; 1. fruit. m,n. T. mameluco - m. leaf; n. fruit. (a,b. E.O. Moura 402; c-e. A.A. Roque 1088; f,g. R.C. Oliveira et al. 1735; h-j. T.A. Barbosa 01; k,1. A. Dantas et al. 178; m,n. R.L. Soares Neto 67). 
Combretum leprosum é uma espécie de fácil identificação, pois apresenta hábito arbustivo escandente, flores com hipanto superior alongadocampanulado e pétalas arredondadas. Apresenta distribuição sul-americana ocorrendo na Bolívia, Brasil e Paraguai (Loiola et al. 2009). No Brasil, C. leprosum distribui-se principalmente na Região Nordeste, mas pode ser encontrada também no Centro-Oeste, Norte e Sudeste do país (BFG 2015). Habita preferencialmente a Caatinga, podendo ser ainda encontrada no Cerrado, Carrasco, Floresta Estacional Decidual e em locais mais abertos como capoeiras, ocorrendo frequentemente em solos arenosos ou pedregosos (Loiola \& Sales 1996). No Rio Grande do Norte, é a espécie com distribuição mais ampla e coletada frequentemente associada à vegetação de SavanaEstépica, em afloramentos rochosos ou não (Fig. 1). Coletada com flores entre fevereiro e agosto e com frutos entre abril e agosto.

No campo, suas inflorescências são vistosas e compostas por muitas flores amareladas, pequenas e perfumadas. Na base da flor, forma um pequeno tubo onde é produzido e armazenado o néctar, sendo este o principal recurso coletado pelas abelhas nativas. Além disso, suas flores são muito atrativas para outros insetos como borboletas, mariposas e vespas (Quirino \& Machado 2001). De acordo com Maia-Silva et al. (2012), Combretum leprosum é uma espécie pioneira, muito resistente e de crescimento rápido, sendo recomendado o seu uso em programas de recomposição de áreas degradadas e também em arborização paisagística. Conhecida popularmente como "mufumbo" (M.L. Silva \& R.C. Oliveira 54).

2.8. Combretum monetaria Mart., Flora, 24(2, Beibl.): 2. 1841.

Figs. $1 ; 4 \mathrm{c}-\mathrm{e}$

Arbustos eretos ou arvoretas, 2-4 m alt., densamente recobertos por tricomas lepidotos hialinos ou ferrugíneos nas porções vegetativas e reprodutivas; ramos acinzentados. Folhas 2,2-6,0 × 1,7-3,0 cm, membranáceas, elípticas a largo-elípticas, ápice agudo, às vezes caudado, base cuneada; nervação eucamptódromabroquidódroma, 4-8 pares de nervuras secundárias; pecíolo 3-4 $\mathrm{mm}$ compr. Inflorescências 6-13 cm compr., racemos subcapitados, paucifloros, axilares ou terminais. Bractéola 1, com 1-2 $\mathrm{mm}$ compr., linear a estreito-oval; botão floral 1,5-4 mm compr., capitado a turbinado. Flores 6-8 mm compr., amareladas; hipanto inferior $1,5-2 \times 0,5-0,6 \mathrm{~mm}$, elíptico a ovoide; hipanto superior $2-2,5 \times 1,5-3 \mathrm{~mm}$, infundibiliformecupuliforme; lobos do cálice $0,5 \times 1,0-1,5 \mathrm{~mm}$, triangulares; pétalas $0,8-1,5 \times 0,4-0,5 \mathrm{~mm}$, espatuladas a obovais. Estames 8, exsertos; filetes do verticilo interno $3-3,5 \mathrm{~mm}$ compr., filetes do verticilo externo $3,5-4 \mathrm{~cm}$ compr.; anteras $0,4-0,5 \times 0,3-0,5 \mathrm{~mm}$, elípticas, alaranjadas; disco nectarífero $0,6-1,0 \mathrm{~mm}$ compr., aneliforme, margem livre, densamente viloso; ovário $0,4-0,6$ $\times 1-1,2 \mathrm{~mm}$, inserido no hipanto inferior; estilete 2,5-3,5 $\mathrm{mm}$ compr., filiforme; estigma punctiforme. Fruto $1-1,4 \times 0,3-0,4 \mathrm{~cm}$, elíptico ou orbicular; alas $0,9-1 \times 0,2-0,3 \mathrm{~cm}$, reflexas; pedicelo frutífero $0,1-1,5 \mathrm{~cm}$ compr.

Material examinado: Campo Redondo, Fazenda Giromão, 616'42”'S, 36¹3'30"W, 5.VIII.2010, fr., A.A. Roque 1088 (UFRN). Equador, 6054'43"S, 36 42'58'W, 754 m, 13.VIII.2015, fr., V.F. Sousa et al. 17 (UFRN). Tenente Laurentino Cruz, 6 $6^{\circ} 11^{\prime} 26^{\prime \prime}$ 'S, 36 $36^{\circ} 43^{\prime} 6^{\prime \prime} \mathrm{W}, 657 \mathrm{~m}$, 9.VIII.2014, fr., B.R.M. Macêdo 31 (UFRN).

Material adicional: BRASIL. PERNAMBUCO: Betânia, Fazenda São Gonçalo, caminho para Serra dos Arrombados, 23.IV.1994, fl. e fr., M.I. Bezerra Neta et al. 149 (HVASF, PEUFR).

Combretum monetaria é facilmente reconhecida pelas flores com pétalas espatuladas ou obovadas e principalmente pelo fruto elíptico a orbicular. A espécie é exclusiva da flora brasileira com ocorrências na Bahia, Ceará, Maranhão, Paraíba, Pernambuco, Piauí e Goiás (BFG 2015). Desenvolve-se em ambientes quentes e secos do domínio da Caatinga, em solos pedregosos, arenosos ou areno-argilosos (Loiola \& Sales 1996). No Rio Grande do Norte, a distribuição desta espécie também está associada à vegetação Savana-Estépica (Fig. 1). Coletada com frutos em agosto.

3. Conocarpus L., Sp. Pl. 1: 176. 1753.

3.1. Conocarpus erectus L. Sp. Pl. 1: 176. 1753.

Figs. 2; 4f,g

Arbusto ou arvoreta, 1,5-2 m de alt.; ramos pubérulos, angulosos. Folhas alternas, pecioladas; pecíolo curto 1-2 mm compr.; lâmina foliar 3-9 $\times$ 1,5-4 cm, lanceolada, ápice agudo, base cuneada, glabra, subcoriácea, biglandulosa na base do limbo; nervação broquidódroma, 4-7 pares de nervuras secundárias; domácias lentibuliformes nas axilas da nervura primária com as secundárias na base da face abaxial. Inflorescências em capítulos globosos pedunculados, axilares ou terminais. Bractéola 1, ca. 1,5 × 0,6 mm, lanceolada, tomentosa, ápice acuminado e viloso. Flores inconspícuas, ca $2 \mathrm{~mm}$ compr.; hipanto inferior assimétrico, 
comprimido, pubescente, côncavo-convexo, ca. 1,2 $\mathrm{mm}$; hipanto superior cupuliforme, ca $1,3 \times$ $1,3 \mathrm{~mm}$, esparsamente tomentoso; cálice 5-lobado, ca. 0,4 mm compr., triangulares, glabros; pétalas ausentes; estames 5, inclusos; filetes filiformes, ca. 1,2 mm compr., anteras orbiculares, ca. 0,3 $\mathrm{mm}$ compr.; disco nectarífero curto, ca. $0,4 \mathrm{~mm}$, carnoso, lobado, pubescente; ovário ca. $1 \times 0,4$ $\mathrm{mm}$; estilete ca. $1 \mathrm{~mm}$ compr.; estigma truncado. Fruto drupáceo, 2,8-3,5 cm compr., agrupados em capítulos globosos, suberoso-coriáceos, imbricados, reflexos, escamiformes, encurvados, obovoide, 2-alados; alas laterais rígidas, glabras, inconspícuas, geralmente hipanto superior persistente.

Material examinado: Macau, Reserva Ponta do Tubarão, 18.III.2006, fr., M.I.B. Loiola (UEC 152733). Tibau do Sul, distrito de Sibaúma, margem do Rio Catú, 15.VII.2006, fl. e fr., R.C. Oliveira et al. 1735 (MOSS, UFRN).

Conocarpus erectus é facilmente reconhecida pelas flores inconspícuas (ca. $2 \mathrm{~mm}$ compr.) e frutos drupáceos, agrupados em capítulos globosos, escamiformes. Distribuída nas áreas litorâneas da África Ocidental (Marquete 1984; Marquete \& Valente 1997), no litoral meridional da Flórida, México, América Central e na América do Sul, onde ocorre do Equador ao Brasil (Linsingen et al. 2009). No Brasil há registros para as regiões Norte, Nordeste, Sudeste e Sul (BFG 2015). No Rio Grande do Norte foi registrada em vegetação de Manguezal, com flores em julho e frutos em março e julho.

4. Laguncularia C.F. Gaertn., Suppl. Carp. 3: 209 (t. 217, f. 3). 1807.

4.1. Laguncularia racemosa (L.) C.F. Gaertn., Suppl. Carp. 3: 209 (t. 217, f. 3). 1807.

Figs. 2; 4h-j

Árvores, 2,5-8 m alt. Folhas opostas, pecioladas; pecíolo 0,8-1,6 cm compr., avermelhado a marrom, com duas glândulas secretoras de sal evidentes na parte distal; lâmina foliar 3,4-9,3 × 2,1-5,1 cm, elíptica, oblongo-elíptica ou obovada, ápice emarginado ou obtuso, base obtusa, glabra em ambas as faces; nervação broquidódroma. Inflorescências em panículas de espigas axilares ou terminais, 4-16 cm compr., laxas, paucifloras; bractéola 1 , com 1,2 × 1,2 mm, cimbiforme, puberulenta. Flores $4 \mathrm{~mm}$, alvo-esverdeadas; hipanto inferior 2,0 $\times 1,3 \mathrm{~mm}$, campanulado, com duas bractéolas adnatas à porção distal; hipanto superior 1,1-1,8 × 2,8-3,5 mm, cupuliforme; lobos do cálice 5 , ca. $1-1,1 \times 0,8-1,3 \mathrm{~mm}$, triangulares; pétalas 5 , ca. $1,5 \times 1,4 \mathrm{~mm}$, orbiculares; estames 10, inclusos, em um único verticilo, filetes ca. 1 $\mathrm{mm}$ compr.; anteras $0,6 \times 0,4 \mathrm{~mm}$, cordiformes; disco nectarífero $0,6-1 \mathrm{~mm}$ compr., aneliforme, com margens livres, esparsamente viloso; ovário ca. $1 \times 0,5 \mathrm{~mm}$, cilíndrico; estilete ca. 1,2 mm compr., filiforme; estigma capitado. Fruto 1-1,3 $\times 0,4-0,5 \mathrm{~cm}$, obovado, estriado, lobos do cálice persistentes.

Material examinado: Areia Branca, Salina Augusto Severo, 11.V.2007, fr., A.A. Roque 42 (UFRN). Grossos, estrada para Tibau, na borda do mangue, 12.XII.2006, fl., A.A. Oliveira et al. 1836 (MOSS, UFRN). Macaíba, 3.II.2015, fl. e fr., T.A. Barbosa 01 (UFRN). Macau, Ilha da Missa, RDS Estadual Ponta do Tubarão, 11.V.2008, fr., J.L.Costa-Lima 12 (UFRN).

Laguncularia racemosa caracteriza-se pela presença de duas glândulas secretoras de sal na parte distal do pecíolo e hipanto inferior com duas bractéolas adnatas à porção distal. É uma espécie típica de mangues pantanosos nas costas do Atlântico e do Pacífico (Stace 2010) e sua presença é considerada ecologicamente essencial para a manutenção da dinâmica desse ecossistema e a sobrevivência de seus organismos (Loiola 2009b). De acordo com Linsingen et al. (2009), L. racemosa floresce e frutifica durante todo o ano. No Brasil, a espécie está registrada em quase todo o país, exceto para a Região Centro-Oeste, desenvolvendo-se nos domínios fitogeográficos da Amazônia e Mata Atlântica, em vegetação de Manguezal e Restinga (BFG 2015). No Rio Grande do Norte ocorre também no litoral, associada à vegetação de Manguezal (Fig. 2). Coletada com flores em dezembro e fevereiro e com frutos em fevereiro e maio.

5. Terminalia L. Syst. Nat., ed. 12. 2: 665, 674. 1767.

Árvores. Folhas simples, alternas, aglomeradas no ápice dos ramos, geralmente com um par de glândulas na base da lâmina foliar ou no pecíolo. Inflorescências em espigas ou panículas de espigas, terminais ou axilares. Flores sésseis, verdes ou esbranquiçadas, andróginas ou unissexuadas, às vezes na mesma inflorescência. Hipanto inferior fusiforme, cilíndrico ou 4-5 anguloso; hipanto superior campanulado, 5-lobado, lobos conspícuos. Pétalas ausentes. Estames 10, inseridos em dois verticilos; anteras versáteis. Disco nectarífero conspícuo, piloso. Ovário 2-óvulos, estilete filiforme. Fruto betulídio, ovalelíptico, comprimido ou alado, seco ou carnoso, coriáceo, geralmente 2-5 alado. 
Terminalia abrange cerca de 200 espécies com ampla distribuição nas regiões tropicais da América, África, Oceania e Ásia (Stace 2002, 2010). No
Brasil, o gênero está representado por 22 espécies (das quais oito são endêmicas) com ocorrência confirmada em todos os estados do país (BFG 2015).

\section{Chave de identificação das espécies de Terminalia ocorrentes no Rio Grande do Norte}

1. Frutos drupáceos, ovoides, ligeiramente comprimidos, não alados 5.2. Terminalia catappa

1'. Frutos betulídios, transversalmente oblongos; alados; alas 1,5-6 mm de largura.

2. Folhas coriáceas, obovadas, ápice arredondado, retuso a emarginado; nervação eucamptódroma, 5 pares de nervuras secundárias; pecíolo 6-10 mm compr., glândulas presentes; fruto 4-alado....

5.1. Terminalia amazonia

2'. Folhas cartáceas, elípticas a obovadas, ápice acuminado ou subagudo; nervação eucamptódromabroquidódroma a broquidódroma, 5-8 pares de nervuras secundárias, pecíolo 3-5 mm compr., glândulas ausentes; fruto 2-alado 5.3. Terminalia mameluco

5.1. Terminalia cf. amazonia (J.F. Gmel.) Exell, Fl. Suriname 3: 173. $1935 . \quad$ Figs. 2; 4k,1

Árvore ca. $10 \mathrm{~m}$ alt., glabra. Folhas 4,6-5,3 $\times 2,2-3,3 \mathrm{~cm}$, coriáceas, obovadas, glabras, ápice arredondado, retuso a emarginado, base atenuada; nervação eucamptódroma, 5 pares de nervuras secundárias; pecíolo ca. 6-10 mm compr.; glândulas 2 , na junção da lâmina com o pecíolo. Inflorescências 6,5-9,4 cm compr., espigas densifloras, axilares; bractéola, botões florais e flores não observadas. Fruto ca. 0,7 × 1,3 cm, 4-alado, transversalmente oblongo; alas desiguais, 2 alas ca. $6 \times 7 \mathrm{~mm}$ e 2 menores ca. $5 \times 1 \mathrm{~mm}$, corpo $6 \times 2 \mathrm{~mm}$; pedicelo frutífero não observado. Material examinado: Nísia Floresta, Mata da EflexIbama, 25.XI.1994, veg., M.S.B. Freire (EAC 24866). Tibau do Sul, 9.XI.1984, veg., A. Dantas et al. 178 (IPA). Material adicional examinado: BRASIL. PERNAMBUCO: Camaragibe, Pau Ferro, lado direito da estrada de Aldeia, 18.XII.1951, fl. e fr., A. Ducke 77 (EAC, IPA).

Terminalia amazonia pode ser reconhecida pelas folhas coriáceas com duas glândulas na junção da lâmina com o pecíolo, nervação eucamptódroma com 5 pares de nervuras secundárias, fruto 4-alado, com 2 alas maiores e 2 menores. Segundo Stace (2010), a espécie distribui-se do México e América Central até a América do Sul, na Bolívia. No Brasil tem ocorrência confirmada na porção norte do país e foi registrada nos estados do Acre, Amazonas, Amapá, Pará e Maranhão (BFG 2015). O espécime coletado no município de Nísia Floresta apresenta apenas porções vegetativas, o que dificulta a diferenciação entre Terminalia amazonia e $T$. glabrescens e a confirmação da identidade do espécime. Neste estudo, o espécime é designado como $T$. cf. amazonia devido às folhas obovadas e ausência de domácias marsupiformes com tufos de tricomas rufescentes, sendo esta última, uma característica marcante das folhas para identificação de T. glabrescens (Marquete 2003; Ribeiro et al. no prelo). Sendo confirmada sua identidade como T. amazonia, constitui nova ocorrência para o Rio Grande do Norte, sendo registrada apenas em Restinga até o momento, no município de Tibau do Sul. Conhecida popularmente como "imbirinbeira" ou "mirindiba" [M.S.B. Freire (EAC 24866)].

5.2. Terminalia catappa L., Syst. Nat. 2: 674. 1767. Comentários: espécie distribuída na Ásia, Austrália, Polinésia e introduzida nos continentes Americano e Africano (Thomson \& Evans 2006). No Brasil está registrada em quase todos os estados, excetuando Alagoas, Amapá, Goiás, Rio Grande do Sul, Rio de Janeiro e Rondônia (BFG 2015).

Apresenta porte arbóreo, folhas obovadas e com duas glândulas na base da lâmina, margem repanda, botão floral capitado, flores brancoesverdeadas, sésseis e laxifloras, a maioria masculina concentrada na parte distal da inflorescência, as femininas localizadas na base da espiga e com hipanto inferior lageniforme, estames exsertos, frutos drupáceos e ovoides. No Rio Grande do Norte é plantada como ornamental ao longo das avenidas, praças e calçadas, onde cresce como árvore vigorosa, formando uma copa ampla. É conhecida popularmente como "castanhola" ou "chapéu-de-sol". Espécie invasora em áreas de restingas (Plucênio et al. 2013).

Material examinado: Alto do Rodrigues, comunidade Barrocas, 5'24'51'S, 36 $43^{\circ} 7^{\prime}$ 'W, 30.V.2010, fr., D.F. Torres 71 (UFRN). Natal, Campus Universitário da UFRN, 2.VIII.2015, fl. e fr., V.F. Sousa 57 (UFRN). 
5.3. Terminalia mameluco Pickel, Arq. Bot. Estado São Paulo (n.s.) 3(4): 200, tab. 50. 1958.

Figs. 2; 4m,n

Árvore 15-16 m de alt.; glabra. Folhas 3,3-8× $1,5-2,8 \mathrm{~cm}$, cartáceas, obovadas a elípticas, glabras, ápice acuminado ou subagudo, base cuneada; nervação broquidódroma, 5-8 pares de nervuras secundárias; pecíolo 3-5 mm compr.; glândulas ausentes. Inflorescências ca. $10 \mathrm{~cm}$ compr., espigas densifloras, axilares; bractéola 1, 2,5-3 $\times 0,8-1$ $\mathrm{mm}$, cimbiforme; botão floral 3-4,5 × 1,5-2,5 $\mathrm{mm}$, capitado. Flores 5-6 $\times 2-3 \mathrm{~mm}$, amareladas; hipanto inferior 3-3,5 $\times 1-1,5 \mathrm{~mm}$, elíptico; hipanto superior $5 \times 2-3 \mathrm{~mm}$, campanulado; lobos do cálice ca. $1,5 \times 1,5 \mathrm{~mm}$, triangulares, reflexos; filetes do verticilo interno $3-3,5 \mathrm{~mm}$ compr., filetes do verticilo externo ca. $4 \mathrm{~mm}$ compr.; anteras $0,6-0,7 \times$ $0,3-0,6 \mathrm{~mm}$, cordiformes; disco nectarífero ca. 1,2 $\mathrm{mm}$ compr., aneliforme, margem livre, glabrescente a pubescente; ovário $0,8-1,5 \mathrm{~mm}$ compr.; estilete ca. $5 \mathrm{~mm}$ compr., linear, pubescente na porção basal até metade do comprimento; estigma truncado. Fruto 1,8-2 $\times 1,1-5 \mathrm{~cm}, 2$-alado, transversalmente oblongo; alas 1,5-2 × 1,2-2 mm, oblongas ou subtriangulares; região central 1,6-2 × 0,6-0,8 mm; pedicelo frutífero $3,8-4 \mathrm{~mm}$ compr.

Material examinado: Baía Formosa, Mata Estrela, 6'22'10"S, 350'28”'W, 15.XII.2013, fr., R.L. Soares Neto 67 (UFRN). Tibau do Sul, Parque Estadual Mata da Pipa, 614'45”'S, 35³'20”'W, 2.VII.2014, fr., J.G. Jardim et al. 6666 (UFRN).

Material adicional examinado: BRASIL. PERNAMBUCO: Bonito, 10.II.1967, fl. e fr., AndradeLima 67-4938 (EAC, IPA). Nazaré da Mata, I.1955, fl., Coelho de Moraes 1338 (holótipo, SP; isótipo, SPSF).

Terminalia mameluco é facilmente reconhecida pelas folhas obovadas a elípticas e glabras, ausência de glândulas no pecíolo, flores com lobos do cálice reflexos e fruto 2-alado, com alas oblongas ou subtriangulares. É uma espécie endêmica do Brasil encontrada nos domínios fitogeográficos da Caatinga e Mata Atlântica, nos estados da Bahia, Ceará, Pernambuco, Espírito Santo e Minas Gerais (BFG 2015). Alguns exemplares estavam identificados erroneamente como Terminalia argentea, no entanto características essenciais para a definição desta espécie não foram observadas, como fruto com alas arredondadas e presença de indumento argênteo-seríceo (Marquete 2003; Ribeiro et al. no prelo). No Rio Grande do Norte, é uma espécie pouco coletada e está representada por apenas dois registros em um fragmento de Floresta Ombrófila Densa na Reserva Particular do Patrimônio
Nacional (RPPN) Mata Estrela e no Parque Estadual Mata da Pipa (Fig. 2). Coletada com frutos em julho e dezembro. Esse táxon é considerado ameaçado de extinção na categoria vulnerável (Borges et al. 2012).

\section{Agradecimentos}

Ao CNPq, a bolsa de Mestrado concedida ao primeiro autor; à CAPES, a bolsa de Doutorado concedida à segunda autora; aos curadores dos herbários ASE, EAC, FUEL, HEPH, HST, HUEFS, IPA, JPB, MAC, MBM, MOSS, UEC e UFRN, o empréstimo das coleções e atenção durante as consultas às coleções. Maria Iracema Bezerra Loiola e Leonardo M. Versieux agradecem ao CNPq, as bolsas de Pesquisador concedidas. Aos revisores e ao editor L. Giacomin, os comentários ao manuscrito.

\section{Referências}

Acevedo-Rodríguez P (2005) Vines and climbing plants of Puerto Rico and the Virgin Islands. Smithsonian Institution Contributions from the United States National Herbarium 51: 1-483.

Almeida Jr. EB \& Zickel CS (2011) Nota de ocorrência de Manilkara rufula (Miq.) H.J. Lam (Sapotaceae) para o estado do Rio Grande do Norte. Pesquisas, Botânica 62: 381-385.

Assis EM \& Maracajá PB (2007) Impactos ambientais no Assentamento Cabelo de Negro em Mossoró, RN. ACSA - Agropecuária Científica no Semi-Árido 3: 44-56.

Barroso GM, Morim MP, Peixoto AL \& Ichaso CLF (1999) Frutos e sementes - morfologia aplicada à sistemática de dicotiledôneas. Editora UFV, Viçosa. 443p.

Bessa MAP \& Medeiros JF (2011) Levantamento florístico e fitossociológico em fragmentos de caatinga no município de Taboleiro Grande, RN. Geotemas 1: 69-83.

BFG - The Brazil Flora Group (2015) Growing knowledge: an overview of seed plant diversity in Brazil. Rodriguésia 66: 1085-1113.

Borges R, Moraes MA, Monteiro NP, Bevacqua AM, Martinelli G \& Marquete N (2012) Available data and risk assessment of the Brazilian threatened species of Combretaceae. Rodriguésia 63: 31-38.

Brasil Channel (2017) Rio Grande do Norte (RN). Características. Disponível em $<$ http://www. brasilchannel.com.br>. Acesso em 20 julho 2017.

Costa-Lima JL, Loiola MIB \& Jardim JG (2014) Erythroxylaceae no Rio Grande do Norte, Brasil. Rodriguésia 65: 659-671.

CRIA - Centro de Referência em Informação Ambiental (2017) Geoloc. Disponível em <http://splink.cria. org.br>. Acesso em 5 abril 2017. 
ExellAW \& Stace CA(1966) Revision of the Combretaceae. Boletim Sociedade Broteriana 40: 5-25.

Exell AW \& Reitz RP (1967) Combretáceas. In: Reitz RP (ed.). Flora Ilustrada Catarinense, Itajaí. Pp. 1-26.

Ferreira CGT, Oliveira RC, Valls JFM \& Loiola MIB (2009) Poaceae da Estação Ecológica do Seridó, Rio Grande do Norte, Brasil. Hoehnea 36: 679-707.

Flora do Brasil 2020 em construção. Jardim Botânico do Rio de Janeiro. Disponível em $<$ http://floradobrasil. jbrj.gov.br>. Acesso em 12 Setembro 2017.

Forzza RC, Baumgratz JFA, Bicudo CEM, Carvalho Jr. AA, Costa A, Costa DP, Hopkins M, Leitman PM, Lohmann LG, Maia LC, Martinelli G, Menezes M, Morim MP, Nadruz Coelho MA, Peixoto AL, Pirani JR, Prado J, Queiroz LP, Souza VC, Stehmann JR, Sylvestre LS, Walter BMT \& Zappi D (2010) Catálogo de plantas e fungos do Brasil. Instituto de Pesquisas Jardim Botânico do Rio de Janeiro, Rio de Janeiro. 1699p.

Freire MSB (1990) Levantamento florístico do Parque Estadual das Dunas do Natal. Acta Botanica Brasilica 4: 41-59.

IBGE - Instituto Brasileiro de Geografia e Estatística (2012) Manual técnico da vegetação brasileira. $2^{\mathrm{a}}$ ed. Disponível em <http://biblioteca.ibge.gov.br/ visualizacao/livros/liv63011.pdf $>$. Acesso em 15 junho 2015.

IPNI (2017) The International Plant Names Index. Disponível em $<$ http://www.ipni.org $>$. Acesso em 6 abril 2017.

Linsingen LV \& Cervi AC (2008) A família Combretaceae R. Brown nas formações de Cerrado do estado do Paraná, Brasil. Pesquisas, Botânica 59: 211-222.

Lisingen LV, Cervi AC \& Guimarães O (2009) Sinopse taxonômica da família Combretaceae R. Brown na Região Sul do Brasil. Acta Botanica Brasilica 23: 738-750.

Loiola MIB \& Sales MF (1996) Estudos taxonômicos do gênero Combretum Loefl. (Combretaceae R. Br.) em Pernambuco - Brasil. Arquivos do Jardim Botânico do Rio de Janeiro 34: 173-188.

Loiola MIB (2009a) Combretaceae. In: Alves M, Araújo MF, Maciel JR \& Martins S (eds.). Flora de Mirandiba. Associação Plantas do Nordeste, Recife. Pp. 115-118.

Loiola MIB (2009b) Neotropical Combretaceae. In: Milliken W, Klitgård B \& Baracat A (eds.). Neotropikey. Interactive key and information resources for flowering plants of the Neotropics. Disponível em <http://www.kew.org/science/ tropamerica/neotropikey.htm>. Acesso em 15 junho 2015.

Loiola MIB, Rocha EA, Baracho GS \& Agra MF (2009) Flora da Paraíba, Brasil: Combretaceae. Acta Botanica Brasilica 23: 330-342.

Lourenço ARL \& Barbosa MRV (2012) Myrtaceae em restingas no limite norte de distribuição da Mata Atlântica, Brasil. Rodriguésia 63: 373-393.
Louzada RB (2013) Combretaceae. In: Prata APN, Amaral MCE, Farias MCV \& Alves MV (eds.). Flora de Sergipe. Vol. 1. Gráfica e Editora Triunfo, Aracaju. Pp. 108-114.

Magalhães R, Versieux LM \& Calvente A (2014) Aechmea muricata (Arruda) L.B. Sm. (Bromeliaceae: Bromelioideae): a new record of a threatened species for Rio Grande do Norte, Northeastern Brazil. Check List 10: 434-435.

Maia-Silva C, Silva CI, Hrncir M, Queiroz RT \& Imperatriz-Fonseca VL (2012) Guia de plantas: visitadas por abelhas na Caatinga. Editora Fundação Brasil Cidadão, Fortaleza. 191p.

Maracajá PB, Batista CHF, Sousa AH \& Vasconcelos WE (2003) Levantamento florístico e fitossociológico do extrato arbustivo-arbóreo de dois ambientes na Vila Santa Catarina, Serra do Mel, RN. Revista de Biologia e Ciências da Terra 3: 1-12.

Marquete NFS (1984) Combretaceae do estado do Rio de Janeiro. Subtribo Terminaliinae. Rodriguésia 36: 81-104.

Marquete NFS (1995) Combretum Loefling do BrasilSudeste (Combretaceae). Arquivos do Jardim Botânico do Rio de Janeiro 33: 55-107.

Marquete NFS \& Valente MC (1996) Combretaceae. In: Coleção Rizzo. Flora dos estados de Goiás e Tocantins, Brasília 19: 1-59.

Marquete NFS \& Valente MC (1997) Combretaceae. In: Marques MCM \& Martins HF (eds.). Flora do estado do Rio de Janeiro. Albertoa 4: 13-51.

Marquete NFS \& Valente MC (2003) Combretaceae. In: Cavalcante TB \& Ramos AE (eds.). Flora do Distrito Federal, Brasil. Embrapa: Recursos Genéticos e Biotecnológicos 3: 153-170.

Marquete NFS, Teixeira J \& Valente MC (2003) Terminalia L. (Combretaceae) na região Sudeste do Brasil. Rio de Janeiro. Bradea 9: 99-123.

Marquete NFS \& Valente MC (2005) Flora da Reserva Ducke, Amazonas, Brasil: Combretaceae. Rodriguésia 56: 131-140.

Marquete N (2006) Combretaceae. In: Barbosa MR, Sothers C, Mayo S, Gamarra-Rojas CFL \& Mesquita AC (orgs.). Checklist das plantas do Nordeste Brasileiro: Angiospermas e Gimnospermas. Ministério de Ciência e Tecnologia, Brasília. Pp. 58-59.

Melo JIM, Camacho V \& Gustavo R (2008) Nova ocorrência para Stachytarpheta Vahl (Verbenaceae) no estado do Rio Grande do Norte. Revista Caatinga 21: 3-6.

Moura EO, Sousa VF, Soares AS \& Versieux LM (2018) Private environmental consultancy reveals five genera and ten species of Rio Grande do Norte state, northeastern Brazil. Check List 14: 439-451.

Plucênio RM, Dechoum MS \& Castellani TT (2013) Invasão Biológica em Restinga: o estudo de 
caso de Terminalia catappa L. (Combretaceae). Biodiversidade Brasileira 3: 118-136.

Portal Brasil (2017) Estados brasileiros - Rio Grande do Norte. Disponível em <http://www.portalbrasil.net/ estados_rn.htm>. Acesso em 20 julho 2017.

QGIS (2017) Quantum GIS Geographic Information System. Open source geospatial foundation project. Program and manual available at $<$ http://www.qgis. org >. Acesso em 8 abril 2017.

Queiroz RT \& Loiola MIB (2009) O gênero Chamaecrista Moench (Caesalpinoideae) em áreas do entorno do Parque Estadual das Dunas de Natal, Rio Grande do Norte, Brasil. Hoehnea 36: 725-736.

Quirino ZGM \& Machado IC (2001) Biologia da polinização e da reprodução de três espécies de Combretum Loefl. (Combretaceae). Revista Brasileira de Botânica 24: 181-193.

Radford AE, Dickson WC, Massey JR \& Bell CR (1974) Vascular plant systematics. Harper \& Row, New York. 891p.

Ribeiro RTM, Loiola MIB \& Sales MF (no prelo) Flora de Pernambuco, Brasil: Combretaceae. Rodriguésia.

Rocha LNG, Melo JIM \& Camacho RGV (2012) Flora do Rio Grande do Norte, Brasil: Turneraceae Kunth ex DC. Rodriguésia 63: 1085-1099.

Santana JAS, Pimenta AS, Souto JS, Almeida FV \& Pacheco MV (2009) Levantamento florístico e associação de espécies na caatinga da estação ecológica do Seridó, Serra Negra do Norte, RN, Brasil. Revista Verde de Agroecologia e desenvolvimento Sustentável 4: 83-89.

São-Mateus WMB, Cardoso D, Jardim JG \& Queiroz LP (2013) Papilionoideae (Leguminosae) na Mata Atlântica do Rio Grande do Norte, Brasil. Biota Neotropica 13: 315-362.

Soares Neto RLS, Cordeiro LS \& Loiola MIB (2014) Flora do Ceará, Brasil: Combretaceae. Rodriguésia 65: 685-700.
Stace CA (2002) Proposal to conserve Terminalia nom. cons. (Combretaceae) against an additional name, Bucida. Taxon 51: 193.

Stace CA (2010) Combretaceae. Flora Neotropica 107. The New York Botanical Garden Press, New York. 369p.

Thiers B [continuamente atualizado] Index Herbariorum: a global directory of public herbaria and associated staff. New York Botanical Garden's Virtual Herbarium. Disponível em $<$ http://sweetgum.nybg. org/science/ih/>. Acesso em 3 abril 2017.

Thomson LAJ \& Evans B (2006) Terminalia catappa (tropical almond), ver. 2.2. In: Elevitch CR (ed.). Species profiles for Pacific island agroforestry: permanent agriculture resources (PAR). Disponível em $<$ http://www.traditionaltree.org $>$. Acesso em 2 agosto 2015.

Versieux LM, Dávila N, Delgado GC, Sousa VF, Moura EO, Filgueiras T, Alves MV, Carvalho E, Piotto D, Forzza RC, Calvente A, Jardim JG (2017). Integrative research identifies 71 new plant species records in the state of Rio Grande do Norte (Brazil) and enhances a small herbarium collection during a funding shortage. PhytoKeys: 43-74.

Versieux LM, Magalhães R \& Calvente A (2013a) Extension of the Cryptanthus range in Northeastern Brazil with new findings in the phenotypic variation including changes in the trichome's distribution, thus enhancing the understanding of the Cryptanthus zonatus complex (Bromeliaceae). Phytotaxa 109: 54-60.

Versieux LM, Tomaz EC \& Jardim JG (2013b) New genus and species records of Bromeliaceae in the Caatinga of Rio Grande do Norte state, Northeastern Brazil. Check List 9: 663-665.

Weaver PL (1991) Buchenavia capitata (Vahl.) Eichler: Granadillo. SO-ITF-SM-43, Department of Agriculture, Forest Service, Southern Forest Experiment Station, New Orleans. 7p.

\section{Lista de exsicatas}

Andrade-Lima EAC, IPA 67-4938(5.3). Andrade Neto M EAC 15776(2.6). Araújo FS EAC 15728(2.3). Barbosa TA UFRN 01(4.1). Bezerra P EAC 301(2.2). Bezerra Neta MI HVASF, PEUFR 149(2.8). Carrhá A UFRN 2598(2.7). Cestaro LA UFRN 99-009 (1.1), 990190(1.1). Coelho de Moraes SP, SPSF 1338(5.3). Colombo B UFRN 06(2.6). Costa-Lima JL UFRN 617(2.1), 12(4.1). Dantas A IPA 178 (5.1). Ducke A EAC, IPA 77(5.1). Freire MSB 24866(5.1). Garcia GS UFRN 218(2.7). Jardim AB UFRN 253(2.7). Jardim JG UFRN 6666(5.3), 5561(2.7), 5581(1.1), 6255(1.1). Lima JLC UFRN 12(4.1), 19(2.7), 102(2.7). Loiola MIB UEC s.n.(3.1). Macêdo BRM UFRN 31(2.8). Marinho AM UFRN 108(1.1). Melo AV UFRN 01(1.1). Mól DFF UFRN 69(1.1). Moura EO UFRN 595(2.7), 402(2.7). Oliveira AA MOSS, UFRN 1836(4.1). Oliveira ACP UFRN 889(1.1). Oliveira RC ASE, HUAC, HUEFS, MOSS, UFRN 1738(2.2), 1735(3.1), 2137(2.7). Paiva MAG UFRN 17(2.7), 27(2.7); Paiva T MOSS 9(2.5). Paterno GBC UFRN 28(2.7). Queiroz RT UFRN 103(5.3). Ribeiro AA MOSS, UFRN 86(4.1). Roque AA UFRN 33(2.7), 42(4.1), 1570(2.1), 424(2.2), 395(2.2), 857(2.7), 1003(2.7), 1088(2.8). Sarmento AC MBM, NY 749(2.3). Silva AC UFRN 15643(2.7). Silva AF UFRN 92(2.7). Silva MAP EAC 47359 (2.3). Silva ML MOSS, UFRN 54(2.7). Soares AS UFRN 53(2.7). Soares-Neto RL UFRN 67(5.3), 108(2.6). Sousa VF UFRN 86(2.1), 17(2.8), 28(2.4), 57(5.2). Tomaz EC UFRN 27(2.1). Targino MA UFRN 29(2.7). Torres DF UFRN 71(5.2). Trindade A UFRN 222(2.7), 1099(2.7), 1813(2.7). Versieux LM UFRN 565(2.7). 